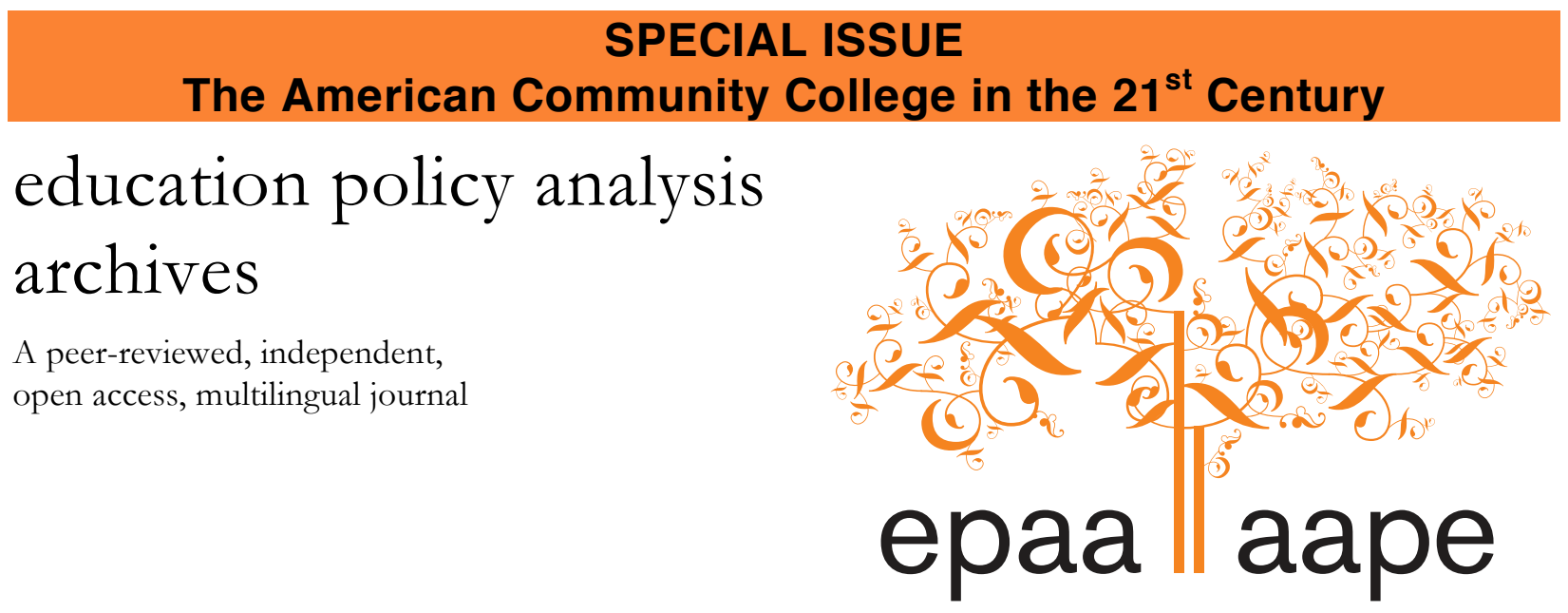

Arizona State University

\title{
The Role of Institutional Agents in Promoting Transfer Access
}

\author{
Alicia C. Dowd \\ University of Southern California \\ United States of America \\ Jenny H. Pak \\ Biola University \\ United States of America \\ Estela Mara Bensimon \\ University of Southern California \\ United States of America
}

Citation: Dowd, A. C., Pak, J. H., \& Bensimon, E. M. (2013). The role of institutional agents in promoting transfer access. Education Policy Analysis Archives, 21(15). Retrieved [date], from http://epaa.asu.edu/ojs/article/view/1187. This article is part of EPAA/AAPE's Special Issue on The American Community College in the 21.t Century, Guest Edited by Dr. Jeanne M. Powers and Amelia M. Topper.

Abstract: A growing body of research points to the important role played by "institutional agents" in facilitating college access and success for students from non-dominant racialethnic and low socioeconomic status groups. Applying attachment theory, this study adds to that literature by demonstrating how institutional agents can provide a secure base, in a 
psychological sense, for such low-status college students in the United States to make successful postsecondary transitions and develop collegiate identities. Based on the life stories of 10 low-status students who successfully transferred from a community college to a selective college or university, our narrative analysis depicts the students' collegiate identity development and how college practitioners in positions of authority were instrumental in raising their collegiate aspirations. The results demonstrate the role of college practitioners in facilitating students' postsecondary transitions and warrant the professional development of faculty and administrators as institutional agents. We conclude by providing resources for practitioners to develop their professional knowledge and capacity to act as institutional agents.

Keywords: community college, transfer, institutional agents, student identity development, professional development.

El papel de "empoderamiento" de los agentes institucionales en la promoción de acceso a través de procesos de transferencia.

Resumen: un creciente conjunto de investigaciones apunta a la importante función desempeñada por "los agentes institucionales" para facilitar acceso a la universidad y el éxito de estudiantes de grupos raciales y étnicos no dominantes y de estatus socioeconómico bajo. Aplicando la teoría del apego (attachment theory en inglés), este estudio fortalece esa literatura demostrando cómo los agentes institucionales pueden proporcionar una base segura, en sentido psicológico, para tales estudiantes universitarios no tradicionales de los de los Estados Unidos y continuar con éxito las transiciones y desarrollar identidades universitarias. Basado en las historias de vida de diez estudiantes de bajo nivel socioeconómico-estado que transfirieron de un community college para una universidad selectiva, nuestro análisis narrativo muestra el desarrollo de la identidad de estudiantes universitarios y cómo profesionales en posiciones de autoridad fueron fundamentales para elevar sus aspiraciones universitarias. Los resultados demuestran el papel de "empoderamiento" de los agentes institucionales en la facilitación de acceso de miembros de la facultad de facilitar las transiciones universitarias y garantiza el desarrollo profesional del profesorado como agentes institucionales. Concluimos con sugerencias de recursos para que los profesores desarrollen su conocimiento profesional y su capacidad para actuar como agentes de cambio.

Palabras clave: Universidades comunitarias (community college); transferencia; agencia; desarrollo de identidades estudiantil.

\section{O papel de "empoderamento" dos atores institucionais na promoção do acesso através de processos de transferência.}

Resumo: Um crescente conjunto de pesquisas aponta para o importante papel desempenhado por "agentes institucionais" para facilitar o acesso à universidade e sucesso de alunos de grupos raciais e étnicos não-dominantes e status socioeconômico baixo. Aplicando a teoria do apego (attachment theory em inglês), este estudo reforça essa literatura demonstrando como agentes institucionais podem fornecer uma base segura, no sentido psicológico, para tais estudantes não-tradicionais universitários dos Estados Unidos continuar com sucesso as transições e desenvolver identidades acadêmicas. Com base nas histórias de vida de 10 estudantes de baixo status socioeconômico transferidos de uma universidade comunitária (community college) para uma faculdade seletiva, a nossa análise narrativa mostra o desenvolvimento da identidade de estudantes universitários e como profissionais em posições de autoridade foram fundamentais para elevar a sua aspirações universitárias. Os resultados demonstram o papel de "empoderamento" dos atores institucionais para facilitar a transição universitária e garantir o desenvolvimento profissional dos professores 
como agentes institucionais. Concluímos com sugestões de recursos para os professores a desenvolver seus conhecimentos profissionais e capacidade de atuar como agentes de mudança. Palavras-chave: universidades comunitárias (community college); transferência; agência; desenvolvimento de identidades estudantis.

\section{Introduction}

Although the debate about the role of community colleges as primarily democratizing or diversionary institutions is longstanding (Brint \& Karabel, 1989; Dougherty, 1994; Melguizo \& Dowd, 2009; Melguizo, Kienzl, \& Alfonso, 2011), it is essential to acknowledge that community colleges and the programs or departments within them can play either role, depending on the conditions of education in any given program and the cultural practices of faculty, administrators, and counselors at the college. Institutional leaders at both community colleges and four-year institutions can take steps to promote a positive transfer culture-just as leaders can play a role in shaping organizational culture in general (Schein, 1991) — and thereby enhance the democratizing functions of community colleges.

Policies and structures that enable transfer from community colleges to four-year colleges or universities may be intended to create a more equitable higher education system. However, they are only partially effective in achieving that goal. Many students do transfer from a community college and graduate with a bachelor's degree, but transfer access to selective institutions is minimal (Dowd, Cheslock, \& Melguizo, 2008; Dowd \& Melguizo, 2008) and the majority of students who enter community colleges with aspirations to transfer ultimately do not ${ }^{1}$ (NCES, 2011). The number of community college transfer students among STEM bachelor's degree holders is also relatively small (Malcom, Dowd, \& Yu, 2010), demonstrating the lack of opportunity for transfer to high status fields of study. State policies designed to encourage curriculum articulation and consistent degree requirements across institutional sectors have not had the desired positive impact on improved equity and efficiency in the multi-tiered, politically stratified system of postsecondary education (Anderson, Alfonso, \& Sun, 2006; Anderson, Sun, \& Alfonso, 2006). The limited impact of policy interventions increases the responsibility of institutional actors at colleges and universities to improve transfer access.

This article draws on empirical data analysis to illustrate the unique and essential role of individuals in positions of authority on college campuses, such as a faculty member, dean, or program director, to assist students in making successful postsecondary transitions and developing collegiate identities. A growing body of literature is demonstrating the importance of "institutional agents" (Stanton-Salazar, 2011, 1997) in schools and colleges in ensuring educational opportunity and success for low-status students, meaning those from non-dominant racial-ethnic and low socioeconomic groups who have traditionally been excluded from higher education. This study adds to that literature by specifying the role institutional agents play in providing a secure base, in a psychological sense, for low-status college students. The findings illustrate the psychological development students experience through positive interactions with institutional actors, which increase the students' capacity to receive and act on pertinent information and opportunities. Institutional agents counter previous negative educational experiences that leave low-status students in an insecure position, in terms of their identity development as college students.

\footnotetext{
1 The National Center for Education Statistics found that 81.4 percent of first-time community college students in the 2004-2009 cohort indicated an intention to attain a bachelor's degree or above. However, only $21.1 \%$ of students in that cohort transferred to a four-year institution within five years.
} 
Based on life stories of 10 purposefully sampled low-status students who successfully transferred from a community college to a selective college or university, our narrative analysis shows how college practitioners in positions of authority were instrumental in raising students' collegiate aspirations and affirming their collegiate identity development. The intervention of institutional agents is particularly important for low-status students, whose home and social environments often do not include adults with first-hand experiences or status in postsecondary education. Family members may provide psychological support in the form of encouragement, but those who are outsiders and lack authority in college settings are not positioned in the same manner as college authorities to convey the sense of belonging and validation that is necessary for students to succeed in college (Rendón, 1993; Hurtado \& Carter, 1997; Rendón, Jalomo, \& Nora, 2000; Museus \& Maramba, 2011).

The findings of the study provide impetus for the professional development of faculty as institutional agents. Therefore, in the concluding sections, we draw on the empirical findings of this study and a broader body of literature to highlight the value of professional development among faculty members and academic leaders as institutional agents. Resources are provided for academics who wish to engage in processes of institutional self-assessment and inquiry, which are integrated aspects of our research agenda. Inquiry is a method of systematic data analysis that supports reflective practice, organizational change, and cultural remediation in support of more equitable educational practices. In this case, the change processes in focus are those that promote the transfer access of community college students to high-value fields of study, institutions, and degrees at fouryear institutions.

\section{Conceptual Frameworks}

\section{Psychological Attachment Theory}

Psychological studies emphasize that an individual's capacity to receive and act on pertinent information and opportunities depends on positive psychological states concerning self-efficacy, control, self-worth, and goal motivation. Whether these states are positive or not are, in turn, influenced by a range of factors present to varying degrees in students' home, educational, and social environments (Fishbein, 2000; Fishbein \& Ajzen, 2010; Fishbein, Hennessy, Yzer, \& Douglas, 2003). Drawing on psychological attachment theory developed by Bowlby (1982, 1973, 1980, 1979, 1988), we apply the concept of "emotional and moral support" to illustrate the role of institutional agents in enabling students to move from an insecure sense of belonging in the college setting to secure positions. This study differs from previous studies in the higher education literature that take a deficit view of the socio-psychological condition of low-status students. As scholars have previously emphasized, too many studies, including studies of college persistence and success based on Vincent Tinto's model of social and academic integration (Tinto, 1975), imply social, cultural, or emotional deficiencies on the part of students who are unable to separate sufficiently from their home culture to experience successful integration in college settings (Tanaka, 2000; Tierney, 1992; Guiffrida, 2009; Harper, 2012; Rendón, Jalomo, et al, 2000; Bensimon, 2007; Museus \& Quaye, 2009; Dowd, Sawatzky, et al, 2011).

In contrast, we treat the alienation low-status students experience in higher education as a sign of the poor adjustment colleges and universities have made to a more diverse U.S. population and student body. From this perspective, it is not a sign of maladjustment if low-status students experience a sense of alienation, cultural incongruity, or "otherness" in college settings that are not welcoming or inclusive (Museus \& Quaye, 2009; Trent, Lee, \& Owens-Nicholson, 2006). On the contrary, it is up to educators to find ways to reduce those cultural practices that contribute to the 
discrimination or marginalization experienced by low-status students. Under existing conditions, such psychological reactions are to be expected and, therefore, low-status students need the support of trusted adults with positional and material resources who can act with authority, in both a psychological and sociological sense, to validate students' sense of belonging.

Just as a caregiver provides an attachment relationship critical to an infant's physical and emotional survival and development, deans, program administrators, counselors, and faculty members can play this role and provide a secure base, in a psychological sense, for a student's identity development. With the support of this necessary transitional figure, a student can take advantage of college information and other resources from a position of emotional safety and security. In effect, as we illustrate in our results, the world of the college opens up to students once they develop a secure college identity, but this psychological transition is not available to many low status students in the absence of a supportive individual who is both authoritative and welcoming.

Several studies on adolescent adjustment to college have linked the psychological concept of attachment security with academic, emotional, and social competence (Palladino-Schultheiss \& Blustein, 1994; Rice, Cunningham, \& Young, 1997; Kenny, 1987). Attachment security refers to a cognitive and emotional experience of safety, stability, and belonging. The higher education literature has also emphasized the importance of enabling students to develop a sense of belonging (Hurtado \& Carter, 1997; Museus \& Maramba, 2011) and providing validation (Rendón, 1993; Rendón, Jalomo, \& Nora, 2000) for a student's pursuit of a college education. The importance of faculty members as mentors and role models is also acknowledged (Hurtado et al., 2011; Nora, Cabrera, Hagedorn, \& Pascarella, 1996; Packard, 2011; Packard, Gagnon, LaBelle, Jeffers, \& Lynn, 2011).

Prior studies show a weak correlation between psychological measures of parental attachment and an individual's adjustment to college, leading some to suggest that an individual's perception of support deriving from other interpersonal relationships becomes increasingly important during adolescence and significantly contribute to psychosocial adaptation (Soucy \& Larose, 2000). One study found that when teachers and mentors have expertise in the environmental contexts in which adolescents must adapt the quality of their affective relationships have a determining influence on adjustment. Such relationships with non-kin (i.e. non-family) adult authorities may even compensate for lack of family support and guidance (Pistole, 1989).

Bowlby (1979) suggests that, although especially evident during early childhood, attachment behaviors "characterize human beings from the cradle to the grave" (p. 129). According to attachment theory (Bowlby, 1973, 1979, 1980, 1982, 1988), attachment figures serve as a "secure base" from which children can explore their environments without fear, facilitating the development of social competence and psychosocial adjustment. From birth, children exhibit attachment behaviors that are activated in situations of physical and psychological distress. At such times, children seek to maintain physical or emotional proximity to caregivers for soothing and comfort. Central to the framework of this study, however, the concept of attachment also provides a valuable lens to investigate social-relational behavior across the life span. In adult relationships, attachment creates three important conditions: (1) proximity in times of stress or need, (2) a safe haven offering comfort, encouragement, and support, and (3) a secure base that allows exploration, risk taking, and self-development (Ainsworth, 1991; Doherty \& Feeney, 2004).

Children develop expectations that are incorporated into internal working models of their environments based on their interactions with attachment figures. Secure attachment is also thought to determine adolescents" "expectations and behaviors in subsequent intimate relationships, and facilitates their exploration of the physical and social environment" (Soucy \& Larose, 2000, p. 126). In general, adolescent adjustment to college is challenging. First-generation students and those whose racial, ethnic, or class characteristics place them in minoritized groups in college face greater 
uncertainty about their belonging or fit (Rendón, 1994; Rendón et al., 2000). They often must overcome psychological insecurities about their personal worth and efficacy in the college setting. In many cases, for students from marginalized or oppressed groups, the transition from high school to college, from a community college to a selective university, or into advanced science and mathematics coursework requires a deep-seated identity transformation. This study examines how adult authority figures in postsecondary settings provide a "secure base," in a psychological sense, from which low-status students can explore and competently move across the cultural and social border that divides community colleges and four-year colleges and universities. In this way, psychological theory is brought into direct communication with the sociological and social-network theories of "institutional agents."

\section{Institutional Agents}

In general terms, an institutional agent is a person who has status, authority, and control of resources in a hierarchical system. These individuals act as agents when they use their status, authority, or resources to enable another person to gain access to their high status setting or related networks of opportunity (Stanton-Salazar, 2011). In the educational literature, the term institutional agents refer to non-family individuals who hold positions of power and authority over educational resources (often, most importantly, their own time). Stanton-Salazar, investigating K-12 schooling and access to socially stratified postsecondary opportunities, gives special attention to those institutional agents who use their positional and personal resources (i.e. experience, knowledge, networks, and commitments) to assist low-status youth in navigating structural and interpersonal barriers to educational success (Stanton-Salazar, 1997, 2001, 2011), in which case, he refers to them as "manifesting" their potential (p. 1067) to serve as institutional agents. By focusing on the characteristics, behaviors, and roles of institutional agents who manifest their potential in this way, Stanton Salazar narrows the term "institutional agent" to refer to those agents who use their status to confer opportunities on those with low social status.

In his most recent work, Stanton-Salazar (2011) further delineates his focus by introducing the concept of "empowerment agents," who are a particular type of institutional agent. Like other institutional agents, empowerment agents provide low-status students with emotional support and access to resources through their networks. However, when institutional agents are functioning as empowerment agents, they do so not merely by promoting individual status attainment, but by participating with low-status students, practitioner colleagues, and advocacy groups in fostering a critical awareness of the social structures and conditions of educational stratification that restrict access to high status resources and opportunities. Empowerment agents also act to fill "structural holes" (Stanton-Salazar, 2011, p. 1095) that disadvantage low-status youth by using their networks to create a bridge to resources in other settings. Whereas institutional agents might be motivated by a liberal, progressive point of view to assist the disadvantaged, empowerment agents are motivated by what Freire termed a "critical consciousness (conscientizacao)"(Stanton-Salazar, 2011, p. 1089). Empowerment agents are not motivated by the desire to teach students how to get by in the existing system, but rather how to "change the world" (Stanton-Salazar, 2011, p. 1093).

To clarify the many ways and arenas in which institutional agents act, Stanton-Salazar (2011) recently delineated fourteen institutional agent roles, characterized by behaviors grouped in four categories. He termed these four categories as direct support, integrative support, system development, and system linkage and networking support (for an application to higher education, see also Bensimon \& Dowd, 2012). Generally speaking, institutional agents provide direct and integrative support in direct communication, relationship, and coordination with students; they provide system linkage and networking support in communication with students and with other institutional agents; and they carry out system developer roles by coordinating with other 
practitioners or accessing resources controlled by others on their campus or in other educational settings. The system developer roles are enacted, not through interaction with students, but with or through colleagues, for example by changing policies and practices related to recruiting, admissions, assessment, evaluation, mentoring, and professional development. For example, the system developer may be involved in creating new programs (such as transfer programs) or taking steps to change admissions or financing policies to extend access to existing programs to low-status students (such as community college students).

Institutional agents can be contrasted with a student's "protective agents": parents, extended family members, and peers who "have the best interest of the student in mind and care the most about their futures" (Teranishi \& Briscoe, 2006, p. 598). As illustrated in a study by Museus and Neville (2012), like protective agents, the institutional agents students encounter at college also typically express care for students' well being and have a personal relationship with them. Through interviews with 60 Asian American, Black, and Latino undergraduates, Museus and Neville found that institutional agents who facilitate racial minority student success "a) share common ground with those students; b) provide holistic support..., c) humanize the educational experience and d) provide proactive support" (p. 436).

Studies in the field of higher education of institutional agents emphasize the role college faculty, leaders, academic program heads, and professionals in student affairs play in mediating access to and success in college for students who have experienced racial discrimination and economic injustice (Bensimon, 2007; Bensimon \& Dowd, 2009; Bensimon, Dowd, Alford, \& Trapp, 2007; Cejda, Casparis, Rhodes, \& Kelly, 2008; Dowd, 2010; Dowd et al., 2006; Dowd, Sawatzky, Rall, \& Bensimon, in press; González, Stone, \& Jovel, 2003; Museus \& Neville, 2012; Teranishi \& Briscoe, 2006) The greatest attention has been given to the ways that institutional agents provide students with information about the cultural expectations of college, assist them in navigating bureaucracies, facilitate access to educational resources, and provide emotional support. As in the study reported in this article, we have in particular examined the role of institutional agents in promoting community college student transfer to selective institutions and to bachelor's and professional degrees in science, technology, engineering, and mathematics (STEM) (Bensimon \& Dowd, 2012; Bensimon et al., 2012; Chase, Bensimon, Shieh, Jones, \& Dowd, in press; Dowd et al., in press).

These are important focal areas of study because if community colleges are to truly play a democratizing role, they will provide access to elite, socially valued, and high status professions for students who could not initially gain admission to four-year institutions due to disadvantages in their primary and secondary schooling. The transfer function is particularly emblematic of social stratification in U.S. higher education and it is also one marked by "structural holes," such as poor curriculum alignment, notably different student financing systems, and near-total separation of faculty members in the two settings. Based on the point of view of purposefully sampled former community college students who successfully transferred to selective institutions, this study takes the transfer process and organizational function as the setting in which to illuminate the ways college practitioners function as institutional agents to assist low-status students.

\section{Practice Theory, Action Research, and Inquiry}

The functions, characteristics, and behaviors of institutional agents have mainly been explicated in a sociological sense, drawing on network theories (Teranishi \& Briscoe, 2006). What is less well understood, and which we illuminate through this study, are the psychological aspects of the agent-student relationship. The empirical results reported in this article reflect student perspectives and voices, which we recognize as important motivators of practitioner agency on behalf of students' well being. As noted above, however, the roles and behaviors of institutional 
agents extend beyond personal relationships with students and are enacted, at times, independently of any relationship with particular students. Institutional agents are motivated not only through caring, but through a critical consciousness of social and educational inequities (Bensimon \& Dowd, 2012; Bensimon et al., 2012; Chase et al., in press; Dowd et al., in press; Stanton-Salazar, 2011).

When it comes to providing students with direct and integrative support, practitioners can act with discretion to align their own practices with students' needs. When it comes to providing networking support and acting as a system developer, practitioners typically require the support and collaboration of their peers to bring about change. Practitioners also encounter educational policies that can facilitate or diminish the prospects of bringing about change on behalf of equity goals. Therefore, our studies of institutional agents in higher education also draw on theories of professional practice and organizational change (Bensimon \& Malcom, 2012; Polkinghorne, 2004), which are situated within a larger mixed methods action research agenda (Bensimon, 2007; Bensimon, Polkinghorne, Bauman, \& Vallejo, 2004).

The results of studies conducted in this integrated manner are reported to the field through journal and other publications but, in addition, also inform the action research design of "tools" (i.e. protocols or artifacts) for practitioner inquiry (Reason, 1994; Witham \& Bensimon, 2012) into the conditions of educational practice that have a negative impact on low-status students. As action researchers, we develop, field test, evaluate, and refine action research tools from a critical, raceconscious perspective to embed indicators or prompts that ask practitioners to reflect on what types of professional actions and behaviors are necessary and appropriate to address inequities. This strategy bears resemblance to the "benchmarking" of "best practices" (Bender \& Schuh, 2002; Doerfel \& Ruben, 2002; Dowd, 2008; Dowd \& Tong, 2007; Seybert, 2004) in that the prompts are generated through literature reviews or case studies of purposefully sampled exemplars, where the exemplars are individuals or groups of practitioners whose professional practices, behaviors, roles, and dispositions distinguish them as institutional agents.

Action research is a methodology developed specifically to navigate the challenges of bringing about changes in organizational cultures and structures (Bensimon et al., 2004; Greenwood \& Levin, 1998, 2005; Kemmis \& McTaggart, 2000, 2005; Noffke, 1997). To relate what we learned through the life history interviews of students who had successfully transferred to an organizational change process, we carried out the interviews as part of a larger set of interrelated mixed-methods studies aimed at improving transfer access and equity ${ }^{2}$ (Bensimon, 2007; Dowd, 2010; Gabbard et al., 2006). The life history interviews were one component among several others. First, statistical analyses of national data characterized the problem of poor transfer access to selective universities (Dowd et al., 2008; Dowd \& Melguizo, 2008) and examined the degree to which those few students who did transfer were able to complete a degree (Melguizo \& Dowd, 2009). Second, a case study of purposefully sampled exemplar institutions was conducted to identify policies and practices at selective colleges and universities that create a transfer-amenable culture (Gabbard et al., 2006). Third, a transfer self-assessment inventory (SAI) was designed, with one version for four-year institutions and one for community colleges, where indicators of exemplary transfer policies and practice were presented as prompts for practitioner inquiry and reflective practice (Dowd, 2010).

The community college transfer SAI was then pilot tested (with modifications appropriate to the field setting) through an action research project at Long Beach City College (LBCC) ${ }^{3}$ (Bensimon et al., 2007), where approximately 20 faculty, counselors, and program administrators used the indicators of exemplary practice to investigate their own transfer culture (Dowd, Bishop, Bensimon,

${ }^{2}$ Funded by the Jack Kent Cooke Foundation, Lumina Foundation for Education, and the Nellie Mae Education Foundation

${ }^{3}$ Funded by the William and Flora Hewlett Foundation 
\& Witham, 2011). The results of inquiry and reflective practice led to a number of reforms at LBCC, including the creation of a transfer academy and a greater awareness of the need for faculty involvement in transfer counseling.

In order to further the development of these inquiry protocols, we included an action research design component in a subsequent study focused on transfer access for Latino community college students in STEM fields ${ }^{4}$. Again, statistical analyses were conducted to characterize the problem of inequitable access (in this case, for Latino students, the focus of the study) (Dowd \& Malcom, 2012; Dowd, Malcom, \& Bensimon, 2009; Dowd, Malcom, \& Macias, 2010; Malcom, 2008; Malcom \& Dowd, 2012) and case studies carried out to identify exemplars of practice (Bensimon \& Dowd, 2012; Bensimon et al., 2012; Chase et al., in press; Dowd et al., in press). These results informed the design of vignettes and self-assessment inventories intended as resources for practitioner inquiry.

Thus, our epistemology relies on the knowledge generated using multiple research methods, deployed in an integrated manner. Conducting action research and facilitating inquiry by practitioners on other campuses is a central component of our work because we believe that changes in practitioner knowledge, beliefs, and practice are necessary to improve equity in higher education. Action research, informed by practice theory, action science, and theories of cognition and learning, calls for practitioner involvement in research or inquiry, which is to say the systematic use of data for problem identification and problem-solving in the practitioner's own setting.

Theoretically speaking, the purpose of inquiry is to enable practitioners to see their cultural practices and institutionalized norms with new eyes, to question the normalcy and appropriateness of those practices, and to motivate change in those practices (where needed). The tensions surfaced through inquiry are characterized as "contradictions," which are theorized as the source of learning, change and agency (Engeström, 2010), where agency is a willingness and capacity to change the culture and systems of which one is a part (Seo \& Creed, 2002). Such agency, or motivation for "praxis" (doing the good), is spurred by practitioners' recognition of a failure of professional practice to achieve professional goals. Problems of practice are, therefore, addressed through a cycle of inquiry that involves problem identification, reflection, experimentation with new practices, new knowledge acquired through experimentation, and growing expertise to address the professional failures that have been identified.

Our action research strategy, then, was to provide the tools practitioners need to engage in a structured inquiry process, inviting them to adopt, adapt, and act on the insights generated through their inquiry to adopt the behaviors and roles of "institutional agents." In keeping with this integrated research approach, the concluding section below describes and makes available a variety of tools developed through these studies of practitioners involved in promoting community college to four-year college transfer access for low-status students.

\section{Methods}

\section{Life Story Case Study}

Many strategies of investigation are utilized in qualitative research (e.g., ethnography, phenomenology, grounded theory, case study). In the present study, the life story case study method (Crossley, 2000; Pak, 2006) was chosen because it offers an in-depth way to understand the impact of educational programs, policies, and practices on individuals' lives. The method is particularly useful when the researcher can identify rich cases. A great deal can be learned from a few exemplars

\footnotetext{
${ }^{4}$ Funded by the National Science Foundation
} 
of the phenomenon in question (Merriam, 1988; Patton, 1990). The goal of the life story case study method is to preserve the narrative meaning the participants attach to various situations in their lives. Information is gathered from interview respondents about when and why certain events occurred and why they and the individuals around them took the actions they did (Crossley, 2000; Pak, 2006). Therefore, data are collected primarily through semi-structured, open-ended questions designed to elicit participants' responses in narrative form (Crossley, 2000).

Stake (1995) distinguishes three types of case study-intrinsic, instrumental, and collective.

A collective case study is an instrumental case study incorporating several individual cases to understand the influence of a phenomenon across a number of people's lives. The present study employed the collective or multiple case study method because the goal was to understand an indepth issue (transfer access) by looking at how non-traditional college students overcame barriers to transfer and success at four-year institutions.

The purpose of this study was to gain an understanding of the context of the participants' educational experiences and of the key factors that influenced their decisions to first attend a community college and then transfer to a particular four-year institution. A preliminary list of questions was prepared to guide the overall process of gathering stories from each participant and to stimulate discussion about particular topics, including educational transitions across their life spans. To facilitate the process, participants were provided with the protocol and general guiding questions before the interview. However, because the quality of data gathered in the life story interview depends on the development of trust and openness between the investigator and the respondent, the interviewer deviated from the protocol to engage in conversation with respondents in a manner that would build rapport. By being sensitive to the natural flow of the exchange, the respondent's reaction to questions, and providing the feedback needed to maintain communication, the focus was on exploring the respondent's perspectives and experiences as they emerged during the interview. Particular attention was given in data collection and analysis to the role of adult authority figures in those transitions.

Each interview was approximately one-and-a-half to two hours in length and took place face-to-face or by telephone. The time and location of the interviews were determined by the participants' availability and convenience. Consent to participate in the study as well as to audiotape the interviews were obtained in advance.

\section{Sample}

A total of 10 interviews were conducted with community college graduates who successfully transferred to a highly selective four-year college or university. The sample of students interviewed is summarized in Table 1. All of the participants could be characterized by one or more demographic characteristics as low-status students whether by ethnicity, class, or race. Counselors and faculty members at selective colleges ${ }^{5}$ were asked to nominate participants for this study by providing the names of "low-income" college students who had successfully transferred from a community college to their institutions. These liaisons responded based on their personal knowledge of transfer students and the financial hardships they had faced. This sampling strategy yielded a largely bifurcated sample of older (non-traditional aged) women and traditional college-aged Hispanic students.

Successful transfer was defined as having obtained a bachelor's degree or being poised to graduate. The institutions included three public research universities (two located on the West Coast of the United States and one on the East Coast) and two liberal arts colleges (both on the East Coast). Nominated students were sent a letter introducing the study and recruiting participants.

5 As defined by rankings by Barron's Profile: (Barron's Profiles of American Colleges, 2003, 2005). 
Those who responded to the letter and returned the recruitment information form received followup emails or phone calls to schedule the interview. Prior to scheduling, initial screening was conducted to confirm that the individual met the criteria for inclusion in the sample.

The sample included six women and four men. The West Coast sample, as shown in Table 1, was comprised entirely of Hispanic students of traditional college age (ranging from 20 to 28 years at the time of the interview). With the exception of one male student, the East Coast sample (Table 2) consisted of women of non-traditional college age (ranging from 41 to 52 years), four of whom were Causasian and one African American. The male student was a traditionally aged Caucasian. All of the students were successful community college transfers. At the time they were interviewed, eight had earned the baccalaureate, two were about to graduate; three were pursuing or had completed MA degrees; one was a second-year law student; and another was a second year Ph.D. student.

Table 1

Transfer Students Interviewed

\begin{tabular}{|c|c|c|c|c|c|c|}
\hline Name & Age & Gender & Ethnicity & $\begin{array}{c}\text { Low } \\
\text { Income }\end{array}$ & $\begin{array}{c}1^{\text {st }} \\
\text { Generation }\end{array}$ & $\begin{array}{l}\text { Type of Four-Year } \\
\text { Institution Attended }\end{array}$ \\
\hline \multicolumn{7}{|c|}{ Students from the West Coast } \\
\hline $\begin{array}{c}\text { Liana } \\
\text { Gonzalez }\end{array}$ & 20 & $\mathrm{~F}$ & Hispanic & $\mathrm{N}$ & $\mathrm{N}$ & $\begin{array}{c}\text { West- } \\
\text { Private Research University }\end{array}$ \\
\hline $\begin{array}{l}\text { Julio } \\
\text { Gauna }\end{array}$ & 25 & M & Hispanic & $\mathrm{Y}$ & $\mathrm{Y}$ & $\begin{array}{c}\text { West- } \\
\text { Public Research University }\end{array}$ \\
\hline $\begin{array}{l}\text { Carolina } \\
\text { Armada }\end{array}$ & 26 & $\mathrm{~F}$ & Hispanic & $\mathrm{Y}$ & $\mathrm{Y}$ & $\begin{array}{c}\text { West- } \\
\text { Public Research University }\end{array}$ \\
\hline $\begin{array}{c}\text { Pedro } \\
\text { Contreras }\end{array}$ & 24 & M & Hispanic & $\mathrm{Y}$ & $\mathrm{Y}$ & $\begin{array}{c}\text { West- } \\
\text { Public Research University }\end{array}$ \\
\hline $\begin{array}{l}\text { Manuel } \\
\text { Adelante }\end{array}$ & 28 & M & Hispanic & $\mathrm{Y}$ & $\mathrm{Y}$ & $\begin{array}{c}\text { West- } \\
\text { Public Research University }\end{array}$ \\
\hline \multicolumn{7}{|c|}{ Students from the East Coast } \\
\hline $\begin{array}{c}\text { Lisbeth } \\
\text { Marian } \\
\text { Giles }\end{array}$ & 52 & $\mathrm{~F}$ & Caucasian & $\mathrm{Y}$ & $\mathrm{Y}$ & $\begin{array}{c}\text { East- } \\
\text { Private College }\end{array}$ \\
\hline $\begin{array}{l}\text { Beth } \\
\text { Mills }\end{array}$ & 49 & $\mathrm{~F}$ & Caucasian & Y & $\mathrm{Y}$ & $\begin{array}{c}\text { East- } \\
\text { Private College }\end{array}$ \\
\hline $\begin{array}{l}\text { Alison } \\
\text { Payton }\end{array}$ & 41 & $\mathrm{~F}$ & Caucasian & $\mathrm{Y}$ & Y & $\begin{array}{c}\text { East- } \\
\text { Private College }\end{array}$ \\
\hline $\begin{array}{l}\text { Anna } \\
\text { Muskie }\end{array}$ & 47 & $\mathrm{~F}$ & $\begin{array}{l}\text { African } \\
\text { American }\end{array}$ & $\mathrm{N}$ & $\mathrm{N}$ & $\begin{array}{l}\text { East- } \\
\text { Private College }\end{array}$ \\
\hline $\begin{array}{l}\text { Byron } \\
\text { Harris }\end{array}$ & 23 & M & Caucasian & $\mathrm{N}$ & $\mathrm{N}$ & $\begin{array}{c}\text { South- } \\
\text { Public Research University }\end{array}$ \\
\hline
\end{tabular}

\section{Data Analysis}

Each student's story was carefully examined to determine what special support, assistance, or program(s) helped them to make a successful transition between educational institutions. Narrative analysis was utilized to integrate diverse events, happenings, and actions in individual lives into a coherent story. It focuses on the particular and special characteristics of individual actions and illuminates why individuals act in a certain way. More specifically, the analysis involved narrative configuration -i.e. identifying a thematic thread or plot that synthesizes various elements of collected data into a temporally organized, unified story (Polkinghorne, 1995). This is not to suggest that any order can be imposed on the data arbitrarily. The investigator is guided by the principle that the final story must fit the data and provide a meaningful explanation. The product of the analysis is not 
simply an objective compilation of the data elements collected, but a meaning co-created between the text (transcribed interviews) and the researcher.

Analysis was carried out in two stages, within-case and cross-case, following Merriam (1988). Each case was first treated as a comprehensive case in and of itself. It was examined carefully to learn as much as possible about individual variations and the complex configuration of events and processes surrounding the transfer process.

The audiotapes of the 10 interviews conducted for this study were transcribed verbatim and then transformed into an integrated text for analysis. The purpose of the analysis was to produce storied narratives depicting the temporal unfolding of the participants' experiences within the educational system. Using the "life chapter" approach (Crossley, 2000), the life stories were organized according to the major phases of schooling (i.e., early experience, middle school, high school, community college, transfer to four-year, post-college, future plans). Each of the storied narratives revealed the challenges faced by students in the sample and how they overcame these obstacles in order to make the successful transition from a two-year to a four-year institution.

Once the comprehensive analyses of individual case studies were completed, cross-case analysis was carried out (Pak, 2006; Polkinghorne 1995). The storied narratives of six of the participants in the study were compared and analyzed across cases. The objective of this cross-case analysis was to develop a better description of factors that influenced individuals' transfer success, including the role of adult authority figures. Examining similarities and differences across cases generated insights into the lived experience of transfer from a community college to a selective college or university, as experienced by college students who had reason to doubt their belonging or right to be a student at a selective college or university. These insights were summarized thematically. The themes were further developed by analyzing the remaining four interviews for confirming and disconfirming evidence of the robustness of the themes. Thus, the six storied narratives reported in the following section are based on analysis and synthesis of the data collected from the 10 interviews.

\section{Limitations}

As with most studies, our methods have a number of limitations. Perhaps most important, our sampling does not allow us to understand whether there are equal or greater numbers of students who received the guidance, mentoring, and advocacy of an trusted adult authority figure yet were unsuccessful in the transfer process or failed to pursue their aspirations of transfer to a selective institution. Furthermore, our sample is not as diverse in racial-ethnic terms as we would like it to be and especially in light of the diversity of the community college student body, where African Americans and some Southeast Asian groups (as well as Latinos) are overrepresented (American Association of Community Colleges, 2012; Handel \& Williams, 2012). Relatively young Latina and Latino students are grouped with older adults as "non-traditional" and low-status students. Ideally the sampling would enable greater differentiation and investigation of the differences and similarities of experience as well as the intersectionality of race, class, age, and gender.

The sample is clustered in groups of students who attended West Coast and East Coast colleges, but we are not able to analyze environmental or experiential factors related to differences in the community college systems or campus cultures on the two coasts. Transfer is a much more prominent and historically well integrated feature of the higher education systems in Western states in comparison to the East, where many not-for-profit universities and independent liberal arts colleges were well established long before the public two-year sectors were created. 


\section{Results}

The life stories of the 10 successful transfer students in our sample of low-status college students underscore the human aspects of the transfer process and the significant role played by individual actors in making transfer to a selective institution an attainable option for students from non-dominant socioeconomic groups. The protagonists in the 10 life stories lived in different parts of the country; some were of traditional college-age when they transferred while others were older; a few had worked for many years and raised their own families. Some had experienced homelessness, while others had found it difficult to venture outside the safety of a close-knit family. Each of these life stories is about one person whose experience is not duplicated by the experience of the others. However, these 10 individuals share in common the experience of having been low-income community college students who managed to transfer to a selective college or university and be academically successful there.

The results are reported in three sections. The first illustrates how the lack of role models during students' early schooling inhibits the development of academic and college-going identities. The second section illustrates the role of institutional agents in enabling non-traditional students to navigate postsecondary transitions and, in doing so, to realize that they are "college material," contrary to what had been communicated to them by adult authority figures in their early schooling. The third highlights the importance of special programs for transfer students in providing a "home base" and access to trusted advisors whom they can call "their own." It also speaks to the limits of the role of institutional agents, as illustrated by the challenges students experience in financing their college educations. The participants in the study are referred to using the pseudonyms shown in Table 1, which also reports each individual's demographic characteristics, major field of study, and academic status or degree outcomes.

\section{Lack of Early Role Models and Guidance}

Most students identified their parent(s) or family as having exerted important influences in their early lives. Particularly, the Hispanic participants in the study (who were traditional-age students from the West Coast) described how they gained a general sense that education was the key to a better future, as their families, especially their mothers, encouraged them to do well in school. However, their mothers not having attended college themselves, this maternal guidance lacked specifics on how to achieve this dream. As one of the participants, Julio Gauna, put it, there was no "model." Four Hispanic students (Julio Gauna, Byron Harris, Carolina Armada, Manuel Adelante) mentioned being identified in school as a troublemaker. As a result, they felt estranged from the educational system by the time they reached middle school. These students eventually dropped out of high school and switched to an independent study or continuing education program to complete their general education degrees (GED).

In contrast, the non-Hispanic students described their grade school experiences as being largely uneventful. However, even those who were not labeled as troublemakers did not receive adequate guidance in their early schooling or as they began postsecondary education at a community college. Six of the participants, including Hispanic respondents and those of other ethnicities (Liana Gonzalez, Pedro Contreras, Manuel Adelante, Carolina Armada, Alison Peyton, Lisbeth Marian Giles), described their high school counselors as not very helpful. The counselors did not provide the students with the guidance they needed to understand the differences between two-year and four-year colleges, financial aid packages, application processes, or the types of courses one needs to gain admission and prepare oneself for college. For example, they may simply have been handed a brochure about a local community college. Pedro Contreras, Carolina Armada, and Manuel Adelante 
indicated that the possibility of attending college was never presented to them while they were in high school.

Although none of the participants spoke of their guidance counselors as having been particularly helpful, many of them mentioned a teacher who was both tough and caring. These individuals were recalled as having had a significant influence on their lives. One case in particular illustrated the positive difference one teacher can make in a student's life. Julio Gauna left his regular high school in the tenth grade, but he spoke of an independent study teacher who was instrumental in helping him complete his GED and pursue higher education. The teacher encouraged Julio to think about going to a community college. He also convinced him that transferring to a four-year university was a real option. Julio stated that this teacher was the first person to give him a "model" of what his future could be and how he could get a college degree. Julio explained that what this teacher did was very important for him as a first generation college student because none of his family members or friends could provide advice about college. Julio's mother, aunt, and older brother had earned their GEDs, but college was not a "reality" in his family.

Reflecting back, they felt their guidance counselors did not take the time to explain the higher education system or the application process because they were not considered "college material." The emphasis was on making sure they graduated. As a consequence, they were not given consideration to enroll in college-track courses in high school. For Pedro Contreras, Julio Gauna, Carolina Armada, and Manuel Adelante, it was only later, when they enrolled in various special programs at the community college, such as those provided by Extended Opportunity Programs and Services (EOPS) ${ }^{6}$ and Puente ${ }^{7}$, that they were able to enroll in college preparatory courses. At that time, they received the additional support to develop the basic academic skills (e.g., reading, writing, and mathematics) needed to succeed in transfer-level courses, which is to say those that would count towards a bachelor's degree when they transferred.

Those students who took jobs after finishing high school or earning their GED quickly discovered that their current occupations would not be enough to provide them with the quality of life they desired. As one student, Carolina Armada, aptly explained, during this time she "came into consciousness" about the plight of the working class and recognized the importance of obtaining an education. In various ways, each of the participants in this study got a "wake up call" from their work or life situations that they did not want to be a low-wage earner for the rest of their lives. With the realization that they needed an education beyond secondary school, their different paths all converged on the community college.

Reviewing all the students' experiences prior to enrolling in a community college, one theme seems to stand out. They tended to be "late bloomers" who discovered their academic potential late in life because they were not treated as "college material" during their primary and secondary schooling. This is most obvious among the nontraditional-age, first-generation college students from the East Coast, who said they missed the opportunity to attend college at the traditional age for various family-related reasons: unfortunate circumstances (Lisbeth Marian Giles), not given serious consideration as a result of their working-class background (Beth Mills), and parents' lack of

\footnotetext{
${ }^{6}$ EOPS is a state-funded retention and support program designed to facilitate the success of financially and educationally disadvantaged students. Services provided by EOPS may include academic counseling, financial aid, tutoring, and transfer guidance (California Community College Chancellor's Office).

7 The Puente Project is a nation-wide program, whose mission is to increase the number of educationally disadvantaged students who enroll in four-year colleges and universities, earn college degrees, and return to the community as mentors and leaders to future generations. The program provides academic support, counseling, and mentoring (Puente).
} 
information about the educational system and financial aid in the United States (Alison Peyton). Many of the participants did not understand the value of college degree when they were younger, but became motivated to pursue higher education after their eye-opening experiences in the world of work.

Anna Muskie explained how it is different to be a student when one's "sense of identity," "sense of challenge," and "sense of accomplishment"—as she put it—is wrapped up in doing academic work. Her level of persistence was qualitatively different, driven by this sense of commitment to who she was becoming:

I didn't have the GPA when I was younger that I had when I was older. I didn't have the commitment when I was younger that I did when I went back and... knew that this is what I had to get done for my own sense of identity, for my own sense of challenge, for my own sense of accomplishment. I was not the same person in '97 that I was in 1980.

The community college system essentially gave students who thought they were not college material "a second chance." As described in the next section, their plans upon entering a community college were poorly formed. Significant at this phase of their development was that they had begun to develop an identity as a college student.

\section{The Role of Trusted Authority Figures}

As the students indicated, one of the best aspects of enrolling at a community college was they could take that chance without altering their lives by enrolling in only one or two classes. The majority of participants (8 of 10) indicated that they simply enrolled in classes at the community college without any clear plan. Typically, the students went through the first semester or the first year on their own, without any guidance from faculty or counselors.

Ultimately students encountered a special instructor or a programmatic niche in a campus program that gave them access to educational resources and information. Through these connections, they began to raise their educational aspirations. The positions of those individuals who acted as "institutional agents" for students are summarized in Table 2. Instructors who "cared" about students and their learning-in particular, those who were "tough"--fostered students' academic interests, developed their skills, and bolstered their confidence. The students entered college feeling ill-prepared academically and were grateful when an instructor took them seriously enough to really teach them.

For example, Julio Gauna describes Ms. Raritan his first instructor at the community college, as being "inspirational." She provided the structure and guidance he needed. Ms. Raritan was instrumental in improving Julio Gauna's writing skills, which gave him the confidence to do collegelevel work. Likewise, Anna Muskie praised a community college instructor who was quite challenging in terms of his academic expectations, but at the same time sincerely interested in helping her prepare for a four-year institution:

And I think that also made a difference in my realization that you can...you can bridge from a community college to a stellar four-year college or university.... He brought the realization that it can be done. And also challenged us in our academic performance with critiquing our writing. It's the first time we had been given so many texts to read in one semester. And I thought it was almost obnoxious. But it was a challenge, and I did well, and I continued to take his courses. I think I took three of his courses, because he did inspire me to be my best. And I did feel that he was critiquing me to improve me, and not critiquing me to disprove me.

Anna's distinction here between being critiqued in an academic sense rather than "disproved" reveals the deeply personal meaning she attributed to her prior academic neglect. Her statement 
pairs this notion of proving herself with doing her best academically, but it also connotes that she is motivated to prove she is worthy of the attention the instructor is giving her. For Beth Mills, the attention of a community college professor whom she described as "exceptionally gifted" as a teacher set her brain "on fire." After she had taken several more classes with him, the instructor advised her to transfer and she followed his advice. Beth Mills credits this professor with awakening her passion for the study of critical thinking and her decision to pursue a law degree.

Table 2

The Presence of Institutional Agents in Students' Lives

\begin{tabular}{|c|c|c|}
\hline Name & At the 2-year Institution & At the 4-Year Institution \\
\hline Liana Gonzalez & None & $\begin{array}{c}\text { Faculty member } \\
\text { Peer advisor (orientation program) }\end{array}$ \\
\hline Julio Gauna & $\begin{array}{l}\text { Faculty member } \\
\text { Academic Counselor } \\
\text { Admissions Counselor }\end{array}$ & $\begin{array}{l}\text { Special program director } \\
\text { West-Public Research University advisor }\end{array}$ \\
\hline Carolina Armada & Faculty member & Special program director \\
\hline Pedro Contreras & $\begin{array}{l}\text { Faculty member } \\
\text { Mentor } \\
\text { Admissions Counselor }\end{array}$ & $\begin{array}{l}\text { Special program director } \\
\text { Peer mentor (residence hall advisor) }\end{array}$ \\
\hline Manuel Adelante & Special program director from a 4-year institution & $\begin{array}{c}\text { Faculty advisor } \\
\text { Special program director }\end{array}$ \\
\hline Lisbeth Marian Giles & Tutoring center director & Special program dean \\
\hline Beth Mills & Faculty member & $\begin{array}{l}\text { Faculty members } \\
\text { Special program dean } \\
\text { Staff members }\end{array}$ \\
\hline Alison Peyton & $\begin{array}{l}\text { College dean from a 4-year institution } \\
\text { Special program director } \\
\text { Academic dean from a } 4 \text {-year institution }\end{array}$ & Special program dean \\
\hline Anna Muskie & $\begin{array}{l}\text { Faculty member } \\
\text { Academic dean }\end{array}$ & $\begin{array}{l}\text { Faculty member } \\
\text { Special program dean }\end{array}$ \\
\hline Byron Harris & $\begin{array}{c}\text { Faculty members } \\
\text { Peers advisors (academic advisors) }\end{array}$ & Provost \\
\hline
\end{tabular}

Having had three very influential mentors to guide her, Alison Peyton, for example, was able to articulate clearly what it meant to have these key individuals in her life. She explains that while her husband and family were always very supportive, it was "phenomenal" to have the support of these powerful figures. Each of them was "someone outside" who saw her potential and "went beyond the call of duty" to mentor her.

Mentors like Mr. Rollins provided the encouragement participants in the study needed to overcome psychological barriers or their own feelings of inadequacy. They built students' confidence by believing they could succeed. As a result, they also served as bridges to the higher educational system by transforming what appeared to be an intimidating maze of requirements into realistic goals that could be negotiated step by step. Thus, receiving support and validation from a key figure(s) within the educational institution, someone with the power to guide students through the 
system, seems to play a significant role in shaping students' collegiate aspirations, particularly for first-generation college students who do not have a role model in their own families.

Many participants (Liana Gonzalez, Pedro Contreras, Julio Gauna, Byron Harris) also mentioned peer advisors and counselors who were helpful in terms of providing useful information, increasing their awareness of competitiveness at four-year institutions, and motivating them to build the "whole package" (Julio Gauna). However, from the way participants described different key influences, there is a distinct difference between the type and level of impact made by peer advisors and that of instructors or administrators. While peer advisors were valued for their support and rapport, as well as for providing useful information, the participants did not describe peer advisors as being influential in overcoming a sense of inadequacy or feelings of not being "good enough."

\section{Special Programs as "Home Base"}

As shown in Table 2, many of the key figures students spoke about were administrators of special programs. The recurrence of directors, associate deans, and deans at four-year colleges and universities among those named by students as key figures in their success highlights the importance of the special programs that these individuals directed. Even after transferring, students continued to need validation from faculty and administrators to ensure them they belonged and could succeed.

Students recalled the "shock" of their initial exposure to the academic rigor (e.g., amount and type of critical reading, length of analytical papers) at the university. Even though they had taken transfer courses and earned good grades at various community colleges, they all described feeling overwhelmed and ill-prepared after they transferred. One of the students, Julio Gauna, felt that even though the community college had prepared him in terms of academic content, it had not prepared him for level of rigor. His initial "shock" made him doubt that he belonged. "What am I doing here and why did I come so far?" he asked himself, facing the possibility of failure. Julio found the transfer program at the university incredibly welcoming and supportive. It played a crucial role in helping him get through the first 6 weeks and preparing him for a successful transition throughout the rest of the academic year. Other students shared similar feelings of initial self-doubt. Their involvement in activities sponsored by the college's transfer program facilitated their connection to the campus

Transfer programs seem to provide a solid "home base" for nontraditional students, particularly when housed in a separate physical space where transfer students can gather, regroup, and find comfort and support. Most of all, individual attention from the head of the program seems to provide the important guidance that enables transfer students to take advantage of various resources that are available at the institutional level.

At the four-year institutions, many participants identified the transfer program director (Julio Gauna, Carolina Armada, Pedro Contreras, Manuel Adelante) or academic dean (Lisbeth Marian, Beth Mills, Alison Peyton, Anna Muskie) as the individual who helped them adjust and make a successful transition. They were also very conscious of these individuals' presence in the transfer program, which interestingly was often tied to a specific building or house. They seemed to derive a sense of security from knowing that a key administrative figure at the four-year institution was there on their behalf and would act as their advocate. Many of the low-income, first-generation college students whose educational experiences at the primary level were disheartening as well as inadequate found it very empowering to be able to call a key official individual at the institution "their own." These program directors or deans were available to help the transfer students any time with any difficulties, whether they were personal (as in the case of Pedro Contreras, who needed help to pay his rent) or academic (as in the case of Lisbeth Marian Giles, who received help to drop Latin "honorably" and Manuel Adelante, who received help to find an academic advisor). 
Program directors at the community college were also referenced as important influences on students' plans. One participant in particular, Lisbeth Marian Giles, described the director of the tutoring center at her community college, Mr. Rollins, as someone who mentored and guided her in a very personal way, almost as a father figure. He worked with her one-on-one by researching transfer options on line with her, helping her with applications, including her letter of interest, and physically taking her to interviews. Without his support and encouragement, Lisbeth Marian Giles stated, she would never have thought about applying to a selective liberal arts college, where she was ultimately accepted and awarded a fellowship.

\section{The Limits of Institutional Agents: The Importance of College Affordability and Financial Aid}

The students we interviewed discussed financial difficulties that they experienced at both two-year and four-year institutions. What stood out in all the interviews was the transfer students' fortitude and determination to not let their financial problems prevent them from reaching their educational goals. The sources of financial aid and financial support that the students utilized to pay for college are summarized in Table 3. In respect to the financial challenges students experienced and navigating the procedures necessary to obtain financial aid, the faculty members who had empowered students as learners and successful transfer students played much less of a role. However, even in this realm, a number of institutional agents lent support; for example, one professor hired a student as a teaching assistant, seeing that he needed the extra money to make it through the semester.

The students described many strategies by which they survived from semester to semester. Five of the traditional-age transfer students reported that they worked almost full-time (Liana Gonzalez, Julio Gauna, Pedro Contreras, Manuel Adelante, Byron Harris), often holding several minimum-wage jobs in order to support their education at the community college. Because Byron Harris was technically a dependent of his parents, he did not qualify for any financial aid even though he had to pay for his schooling. This is how he managed to do so:

At [the community college], I worked for most of the time. But, the way finances worked at [the community college], the first...the first semester, I paid for the entire thing on my credit card, and that put me into some debt. The second semester, I paid for most of it with a credit card.

Byron Harris suggests that it would be helpful if community colleges implemented "a payment plan option," especially for students in circumstances like his own.

Although some of the students received financial aid, they mentioned that unavoidable expenses, such as paying for their textbooks, added to the cost of living. Having to juggle school and work in an effort to make ends meet was very stressful for them. Several of the Hispanic male students (Julio Gauna, Pedro Contreras, Manuel Adelante) said they were working almost full-time because they needed to support their families financially (e.g., by helping to pay the rent) even though they were attending school. For Pedro Contreras, things became particularly bad after his single mother became ill and was laid off from work. He recalls how he managed to get through one of the toughest times:

...I was given financial aid during that time, so I had some of my financial aid money to use. I remember I was kind of short as far as rent money and I spoke to one of my English professor there. I let her know what was going on in my situation. So she pretty much hired me to be her TA. At least, I believe it was about 10 hours for the week. So that helped out financially. ...being able to work at school, and being able to manage my schedule, and set up my own schedule. 
Table 3

Sources of Financial Aid and Financial Support Utilized by Students

\begin{tabular}{|c|c|c|}
\hline Name & At the 2-year Institution & At the 4-Year Institution \\
\hline Liana Gonzalez & Worked full-time & $\begin{array}{l}\text { Scholarships } \\
\text { Grants } \\
\text { Work study } \\
\text { Worked full time }\end{array}$ \\
\hline Julio Gauna & Worked full-time & $\begin{array}{c}\text { Scholarships } \\
\text { Financial Aid } \\
\text { Grants } \\
\text { Work study } \\
\text { Worked full time } 1^{\text {st }} \text { yr. \& fewer in } \\
\text { subsequent years }\end{array}$ \\
\hline Carolina Armada & $\begin{array}{c}\text { Grant } \\
\text { Veterans Fee Waiver }\end{array}$ & $\begin{array}{c}\text { Veterans Fee Waiver } \\
\text { Scholarships } \\
\text { Grants } \\
\text { Work study } \\
\text { Loans }\end{array}$ \\
\hline Pedro Contreras & Worked full-time & $\begin{array}{c}\text { Federal \& State Aid } \\
\text { Loans } \\
\text { Scholarship } \\
\text { Work study } \\
\text { External family support }\end{array}$ \\
\hline Manuel Adelante & Grant & $\begin{array}{c}\text { Federal \& State Grants } \\
\text { Scholarships } \\
\text { Work study }\end{array}$ \\
\hline Lisbeth Marian Giles & Worked part-time & $\begin{array}{c}\text { Grants } \\
\text { Loan } \\
\text { Work study } \\
\text { Worked part-time }\end{array}$ \\
\hline Beth Mills & Worked full-time & $\begin{array}{c}\text { Scholarships } \\
\text { Grants } \\
\text { Loans } \\
\text { Retirement savings } \\
\text { Worked part-time }\end{array}$ \\
\hline Alison Peyton & $\begin{array}{l}\text { No information/ } \\
\text { Unknown }\end{array}$ & $\begin{array}{l}\text { Grants } \\
\text { Tuition Remission (employee benefit) }\end{array}$ \\
\hline Anna Muskie & Worked full-time & $\begin{array}{l}\text { Grants } \\
\text { Loans }\end{array}$ \\
\hline Byron Harris & Worked part-time & $\begin{array}{c}\text { Scholarships } \\
\text { Parental support }\end{array}$ \\
\hline
\end{tabular}

Carolina Armada similarly related how she and her family faced an extremely difficult financial situation while she was in community college. At the college, she qualified through a special opportunity program for vouchers to cover the cost of books. She explained that the vouchers were very helpful because the cost of textbooks was often more than the tuition. Unfortunately, during 
her last semester at the community college before she was to transfer to the four-year institution, both her parents lost their jobs and consequently their home of eighteen years, whereupon they became homeless. Her family's financial crisis was devastating, but Carolina indicated that education took on an even greater significance for her, and she became more focused and determined than ever. She reflected on how she managed during this time:

So I was one of those students who's kind of like, in between, where I didn't necessarily completely qualify for financial aid. But then there was the cost of living that really became difficult because I did need, like, I did need support on help in being in school. And that takes up so much of your time that I couldn't work fulltime and do well in school. Like, it seemed like one or the other, work full-time or transfer to [the West-Public Research Institution]. And... and so I think for a while I ended up working two part-time jobs and went to school full-time.

At the four-year institution, aided by some scholarships and a tuition fee waiver as a dependent of a veteran, Carolina Armada decided to take ownership of her education and invest in herself by taking out student loans to cover some of the costs. She not only faced the much higher costs of a four-year institution, but also summer school tuition, which added an additional $\$ 3,000$ to $\$ 4,000$ to her costs. She describes the emotional effort it required to take out loans and spend the money:

So I actually just kinda had to like, put that, put it aside and just seal it, you know. And for me to invest into this and focus. And... and do it. So it was hard because I...I really...I didn't want to have to be so much in debt. But I realized, 'Well, my family can't give me money to go and, you know... I'm just gonna have to take out these loans to...to get by and... and live off of." And just to balance it out with work, and then scholarships and all that.

Carolina Armada's words reflect a certain courage and a sense of risk in taking out a loan, in effect the "psychic costs" of the time and effort invested in college, which increase under greater uncertainty about one's ability to complete college (Dowd, 2010; Nora et al., 1996; Trent et al., 2006).

However, Caroline was an exception among the students in our sample. Two of students (Manuel Adelante and Byron Harris) indicated that their decision about the school to which they would transfer was determined largely by where they could avoid taking out a loan. Byron Harris was accepted to a prestigious private school in his area, but even with financial aid and scholarships, he would have been "short about $\$ 10,000$ a year." Therefore, he decided to transfer to South-Public Research University. Similarly, Manuel Adelante was accepted to a selective West-Public Research University, but he was offered only a Pell grant and would have had to take out a loan. He decided to attend another selective West-Public Research University because he was offered a full scholarship there. Both of these students were able to enroll at an institution of prestige similar to the one they turned down, but it is notable that their concern about borrowing influenced their decisions so strongly.

Other transfer students (Lisbeth Marian Giles, Julio Gauna, Liana Gonzalez) indicated that they worked part-time or additional hours while going to school full-time to avoid taking out a loan and make up for what was not covered under their financial aid package. Liana Gonzalez and Julio Gauna explained that they held two to three jobs simultaneously, often working up to 35 hours per week even after they transferred to four-year universities because they did not want to burden their parents with their educational cost. Although they both had work-study programs, they supplemented the amount provided with income from other part-time employment off-campus. Again this was to avoid taking out a loan. During Anna Muskie's first year at a four-year institution, the dean of her transfer program helped her in finding a work-study program for 10 hours per week 
as a computer intern. According to Anna Muskie, her work-study along with a loan enabled her to "keep things calm" and stay focused on her studies. Other students participated in similar workstudy programs.

Clearly, when it comes to paying for college, financial aid policies and state appropriations that subsidize tuition rates are the key features enabling students to transfer and complete their degrees. Institutional agents can assist students in learning about financial aid resources, in navigating the bureaucracies and procedures that govern the distribution of financial aid, and in giving students confidence that they are worthy of that aid and of investing in themselves. In addition, when faculty or others provide opportunities for work on campus, it enables students to finance their education while staying connected with their academic setting, which is important to mitigate the "pull" factor students experience when working off campus (Nora, 1990).

\section{Discussion}

Building on prior studies of institutional agents who assist low-status students to navigate and succeed in educational systems, this study adds understanding of the importance, from a psychological perspective, of the institutional agent-student relationship. Many of the low-status students interviewed in this study recalled going through the first semester or year at the community college wondering what they were doing there. On transferring to a four-year institution, most of them again felt overpowered by the sheer physicality of the architecture from the moment they set foot on campus (see also Bensimon \& Dowd, 2009). These students were often plagued by feelings of doubt as to whether they belonged at college, particularly at a selective institution. Before enrolling in a community college, many of them had been told explicitly (e.g., Julio Gauna and Lisbeth Marian Giles) or implicitly (e.g., Carolina Armada and Pedro Contreras) in middle or high school that they were not "college material."

Moreover, like many low-income, first-generation students, participants in this study had internalized the negative messages given by insensitive authority figures (e.g., teachers or counselors). Over time, these overt or subtle negative messages were reinforced by other discouraging educational experiences. For this reason, the positive authority figures (e.g., instructors, directors, and administrators) they identified in their storied narratives of their lives played an instrumental role in helping them overcome their internalized feelings of not being good enough or smart enough for college.

By noticing, nurturing, and believing in students' abilities, key individuals had the power to affirm students and influence them to achieve their full academic potential. We see in our study that the transfer students were "late bloomers." With the possible exception of one, all of the successful transfers seemed to discover their full academic potential at the community college. Students attributed their successful personal transformations and transfer experiences to teachers, counselors, and other authority figures who were able to validate their sense of belonging and act as bridges to provide entrée into new academic and social settings.

Noting the limitations of our research design, we do not interpret our results as showing a causal effect of the institutional agents' behaviors on the students' success. There are likely similarly situated students who transfer from community colleges to selective institutions without the assistance of institutional agents. Furthermore, some students who receive the help of institutional agents when at a community college do not transfer or achieve other important educational transitions. That said, as the United States aims to boost the number of college graduates and turns

to community colleges to democratize education providing a gateway for low-status populations, it is clear that practitioners must be kept in mind as essential resources for student success. While this may seem obvious, often attention is invested in creating articulation, guaranteed transfer, or 
financial aid incentives to transfer without a complementary focus on the practitioner's role in helping to realize policy goals.

Our study demonstrates how institutional agents are instrumental in assisting low-status students to traverse the two very different worlds of the community college and the selective college or university. The results of this study contribute four primary insights into the emerging scholarship illustrating the steps college and university practitioners take to manifest the role of institutional agent. First, institutional agents give low-status students permission to take on the identity of a college student (or, in the case of this study, specifically of an elite college student). They do this by taking students seriously as students, setting high academic expectations for them, and providing the necessary guidance to enable students to experience success performing to a rigorous academic standard.

Second, educators in positions of authority appear to play a unique and essential role in validating students' collegiate identity development that cannot be performed by protective agents (parents, family members, peers. This is because many students who are "late bloomers" have previously received and to some extent internalized explicit and implicit messages from educational authority figures in their early schooling that they were troublemakers, not worthy of serious attention, or simply not college material. The affirmation students received from agents who they described as instrumental in their success help them to counter stereotype threat, the fear of living up to expectations of low performance or intellectual inferiority (Teranishi \& Briscoe, 2006).

Third, institutional agents must provide students with a secure base, in both a psychological sense and physical sense, for personal and academic development. This development is ongoing-and the need for reassurance of the support of the institutional agent recurring--because at times of academic or personal challenge, students experienced strong feelings of self-doubt. The institutional agents described by the students in our sample provided a secure base for identity formation by making themselves personally available to students and by taking leading administrative roles in special programs that provided a physical "home base" for students. These physical centers of transfer student communities created access for students to other valuable resources, including peers with similar backgrounds and experiences who shared information and encouragement. Consistent with prior studies (Bensimon \& Dowd, 2009; Museus \& Neville, 2012; Stanton-Salazar, 2011; Teranishi \& Briscoe, 2006), our respondents reported that institutional agents provided emotional support and were "there for them" when they needed help. This sense of proximity was important to bridge the cultural distance that low-income and racially or ethnically minoritized students experience on predominantly white, middle- to upper-class campuses (Museus \& Quaye, 2009).

Fourth, although students described actions of institutional agents who acted on the students' behalf by using their own personal or positional power and by bridging to resources available in other settings to fill structural holes on their own campus, our results do not provide evidence that institutional agents in higher education, acting in the arena of transfer access, manifest their roles in ways focused on changing social structures and educational stratification. In other words, although they are empowering of students in a psychological sense, the institutional agents who helped the students in this study did not appear to be engaging in their current work as social change agents in the critical or political sense of empowerment described by Stanton-Salazar (2011). The results suggest that these institutional agents primarily engaged in helping students by teaching them to navigate collegiate cultures, creating a psychological and physical home base that provided for psychological attachment, and permitting them to acquire a sense of belonging in the existing system. In light of the students' need for a secure base in a culturally foreign setting, these efforts are clearly important. Yet, the student respondents did not articulate exposure to or an invitation to participate in developing a critical consciousness of that system. There were glimmers of this type of awakening, as when Carolina Armada speaks of "coming into consciousness" about her class status, 
but it seems this awakening led mainly to Carolina's personal transformation rather than broader social engagement.

In part, this finding that institutional agents in higher education are not acting as empowerment agents may be due to our sampling and data collection method. We obtained information from the students' point of view and experience. It is possible that the institutional agents who assisted the students in our sample were acting outside of the students' awareness to bring about systemic changes. It is also possible that there were other institutional agents on the students" campuses (or in other settings) who were doing the "counterstratification" work Stanton Salazar (2011, p. 1090) identified as necessary to bring about greater equity in U.S. schooling and higher education. For these reasons, this aspect of our study deserves further investigation using different sampling strategies and research methods. Despite these limitations, this finding deserves attention because it speaks to the political realities of expecting higher education practitioners to act as change agents of higher education.

Although acting to instill a critical consciousness in those around them is one of StantonSalazar's defining characteristics of an empowerment agent, he himself points out the problems with this expectation. Noting that some institutional agents - those who are "socialized into the rule of hierarchy, gate-keeping, and legitimating ideology" — are agents of social reproduction, others "comprise the resistance." A third group, which is perhaps the one best represented by the individuals who played an instrumental role in assisting the students in our study, "are caught within the contradictory dynamics of inequality, gate-keeping and empowerment - a battleground where many institutional agents, particularly within the school system, are subjected to contradictory forces competing over their implicit roles and underlying functions in the stratification system" (StantonSalazar, 2011, p. 1087). As noted in our discussion of practice theory, action research, and inquiry in the conceptual framework section, the contradictions practitioners experience between their social ideals and professional standards, on the one hand, and the realities of being employed in a stratified educational system, on the other, is the exact crux of the challenge of using practitioner inquiry as a method to bring about organizational change in educational institutions.

Noting these challenges, we continue to design action research tools and to collaborate with practitioners to utilize them as part of structured inquiry processes intended to promote reflective practice in groups of practitioners on college campuses. In the following section, we describe a number of the tools that were developed in conjunction with the life history case method component of our study of transfer to selective institutions and with the subsequent case study we conducted of Latino students transfer to STEM bachelor's degrees. .

\section{Resources for Inquiry and Reflective Practice}

Our results provide compelling evidence that transfer-and the realization of community colleges as "democracy's college" in the stratified higher education system-hinges on the formation of instrumental relationships between educational authority figures and students. However, these relationships typically developed informally as, for example, when a program director noticed the potential in a student and reached out to him or her. Although this study as well as others (Bensimon \& Dowd, 2009; Cejda et al., 2008; González et al., 2003; Valenzuela, 1999) provide evidence that institutional agents act to increase students' sense of belonging and effectively facilitate their ability to navigate postsecondary education, the opportunities for faculty or aspiring faculty to receive professional development that will help them assume the role of institutional agents, either in an empowering sense or the more constrained sense of enabling students' individual status attainment, are fairly limited. The approaches and systems for creating institutional agents are simply not well established; in fact, they have not yet been fully conceptualized. The effort is an important one to undertake, however. Our findings illustrate that additional structures, materials, and processes 
must be developed to provide faculty with the training and professional development to intervene on behalf of low-status youth. The findings of this study provide an impetus for creating greater opportunities for faculty and academic administrators to engage in inquiry, because it shows that practitioners are instrumental actors who influence students' educational transitions and outcomes, in this case successful transfer. Therefore, in this section, we describe and provide hyperlinks to resources (summarized in Table 4) that faculty and administrators may use as part of structured inquiry projects to increase their capacity to act as institutional agents. Stanton-Salazar (2011) theorizes that five characteristics will determine whether those who are eligible, by their positional status and personal resources, to act as institutional agents will act as empowerment agents on behalf of low-status youth. Paraphrasing his more detailed descriptions (p. 1089), these five characteristics are, in short:

1. Awareness of the problem of stratification in society and educational systems;

2. Awareness that the success of low-status youth depends on the extent to which they receive support from institutional agents;

3. Willingness not to act on established "rules of social structure that serve the purpose of consolidating resources" at upper levels of the hierarchy;

4. Self-identification as an advocate and the ideological commitments that shape that identity and sense of responsibility for low-status students;

5. Willingness to be identified as an agent and advocate for low-status students by their professional peers.

Characteristic 1, awareness of the problem, maps well to the starting point for inquiry, as explicated by practice theorists. As noted in the discussion of our conceptual framework, inquiry is a process for problem identification, learning, experimentation with problem solving, and the acquisition of new knowledge and beliefs to address identified problems of practice with greater expertise. Thus, inquiry is an appropriate strategy to promote agency (Seo \& Creed, 2002).

Therefore, we have translated our findings from case studies of transfer to selective institutions and to STEM bachelor's degrees into action research tools. These are for use by practitioners as part of reflective practice about their agency on behalf of community college students in general and Latino community college students, who were the focus of our studies of STEM transfer. These tools are resources to faculty and administrators who wish to learn more about inquiry processes and action research designed to address racial-ethnic inequities. They are designed to provide reference points for reflection about what it means to be an institutional agent or an empowerment agent for lowstatus students when it comes to providing transfer access to bachelor's degrees. The resources and readings provided focuse on faculty interactions with or actions on behalf of transfer students through models, vignettes, instructions, and examples of ways to incorporate inquiry into the routine business of postsecondary institutions. Such routines include the work of equity and diversity committees, accreditation self-studies, climate studies, and faculty hiring and professional development.

As mentioned above, in our mixed methods study of transfer access to selective institutions for low-income community college students, we conducted statistical analyses of national data to identify the problem of the limited opportunity community college students have to transfer to a selective institution (see Dowd, Cheslock, \& Melguizo, 2008; Dowd \& Melguizo, 2008). Through statistical analysis, eight four-year institutions that had higher than expected incoming community college transfer rates (based on their institutional characteristics) were also identified and case studies conducted to learn about the exemplary practices that might be taking place at those institutions and their "feeder" community colleges. In addition to producing a report characterizing those practices 
(Gabbard et al., 2006), we created an inquiry tool called the Transfer Self-Assessment Inventory (SAI) (for more information, see Dowd, 2010). As indicated in Section I of Table 3, one version was developed for use in inquiry at selective colleges or universities (Transfer SAI-Four-Year College Version) and one for use at community colleges (Transfer SAI-Two-Year College Version). The SAIs are organized in eight sections, addressing topics such as admissions, recruitment, and orientation in the four-year college version and transfer counseling and advising in the two-year college version. Both versions include indicators concerning financial aid, institutional policies and practices that affect transfer access, and cross-institutional partnerships and collaboration.

Table 4

Resources for Inquiry and Reflective Practice

\begin{tabular}{|c|c|c|c|}
\hline Inquiry Tool $^{8}$ & $\begin{array}{l}\text { Reflective } \\
\text { Practice } \\
\text { Supported at } \\
\text { the Level of } \\
\text { the: }\end{array}$ & Topical Focus & Format \\
\hline \multicolumn{4}{|c|}{ I. Transfer Self-Assessment Inventories } \\
\hline $\begin{array}{l}\text { Transfer SAI-Four-Year } \\
\text { College Version }\end{array}$ & Institution & $\begin{array}{l}\text { (1) Recruitment, admission, and } \\
\text { orientation services; } \\
\text { (2) Financial aid; } \\
\text { (3) Personnel; } \\
\text { (4) Publicity and public } \\
\text { (statements; } \\
\text { (5) Institutional transfer policies } \\
\text { and practices; } \\
\text { (6) Partnerships and collaboration } \\
\text { with community colleges; } \\
\text { (7) Barriers to transfer access; } \\
\text { (8) Institutional mission }\end{array}$ & $\begin{array}{l}\text { Self-assessment inventory } \\
\text { with indicators grouped in } \\
\text { the eight categories of the } \\
\text { topical focus with } \\
\text { behavioral frequency } \\
\text { response scales and Likert } \\
\text { scale assessment of impact } \\
\text { on transfer access. }\end{array}$ \\
\hline $\begin{array}{l}\text { Transfer SAI-Two-Year } \\
\text { College Version }\end{array}$ & Institution & $\begin{array}{l}\text { (1) Transfer counseling services for } \\
\text { students; } \\
\text { (2) Financial support for students } \\
\text { seeking to transfer to selective } \\
\text { four-year institutions; } \\
\text { (3) Personnel; } \\
\text { (4) Publicity and public statements; } \\
\text { (5) Institutional transfer policies } \\
\text { and practices; } \\
\text { (6) Partnerships and collaboration } \\
\text { with selective four-year } \\
\text { institutions; } \\
\text { (7) Barriers to transfer access; } \\
\text { (8) Institutional mission }\end{array}$ & $\begin{array}{l}\text { Self-assessment inventory } \\
\text { with indicators grouped in } \\
\text { the eight categories of the } \\
\text { topical focus with } \\
\text { behavioral frequency } \\
\text { response scales and Likert } \\
\text { scale assessment of impact } \\
\text { on transfer access. }\end{array}$ \\
\hline
\end{tabular}

${ }^{8}$ Click on the text in the first column for hyperlinks to PDF documents and related content on the Center for Urban Education (CUE) web site (http://cue.usc.edu/). 


\begin{tabular}{|c|c|c|c|}
\hline${\text { Inquiry } \text { Tool }^{9}}^{2}$ & $\begin{array}{l}\text { Reflective } \\
\text { Practice } \\
\text { Supported at } \\
\text { the Level of } \\
\text { the: }\end{array}$ & Topical Focus & Format \\
\hline \multicolumn{4}{|c|}{ I. Transfer Self-Assessment Inventories } \\
\hline $\begin{array}{l}\text { The "Missing '87":A } \\
\text { study of the "transfer } \\
\text { gap" and "choice gap" }\end{array}$ & Institution & $\begin{array}{l}\text { (1) Transfer counseling services } \\
\text { for students; } \\
\text { (2) Financial support for students } \\
\text { seeking to transfer to four-year } \\
\text { institutions; } \\
\text { (3) Institutional transfer policies } \\
\text { and practices; } \\
\text { (4) Partnerships and } \\
\text { collaborations. }\end{array}$ & $\begin{array}{l}\text { Action research project } \\
\text { report with comprehensive } \\
\text { inquiry findings concerning } \\
\text { transfer barriers and } \\
\text { recommendations for } \\
\text { potential solutions to } \\
\text { increase transfer. Appendix } \\
\text { C provides a summary of } \\
\text { the indicators of effective } \\
\text { transfer practice used as } \\
\text { prompts for inquiry in this } \\
\text { project. }\end{array}$ \\
\hline \multicolumn{4}{|c|}{ II. CUE Published Reports with Data Tools and Narrative Profiles } \\
\hline $\begin{array}{l}\text { Community College } \\
\text { Change Agents at HSIs: } \\
\text { Stewarding HSI-STEM } \\
\text { Funds for Latino Student } \\
\text { Success in STEM. }\end{array}$ & $\begin{array}{l}\text { Individual } \\
\text { and Program } \\
\text { and } \\
\text { Institutional } \\
\text { (Community } \\
\text { Colleges) }\end{array}$ & $\begin{array}{l}\text { Profiles of two professors } \\
\text { (Benjamin Rivera, Yolanda } \\
\text { Velasco) and a high level } \\
\text { administrator (Jeffrey Carter) } \\
\text { depicting change processes to } \\
\text { support culturally responsive } \\
\text { pedagogies and the use of routine } \\
\text { college data in inquiry focused on } \\
\text { including Latinos in STEM. } \\
\text { Definitions and recommendations } \\
\text { for using performance, diagnostic, } \\
\text { and process benchmarking in } \\
\text { inquiry. }\end{array}$ & $\begin{array}{l}\text { CUE Report: Bensimon, E. } \\
\text { M., Dowd, A. C., Chase, M. } \\
\text { M., Sawatzky, M., Shieh, L. } \\
\text { T., Rall, R. M. \& Jones, T. } \\
\text { (2012). }\end{array}$ \\
\hline $\begin{array}{l}\text { Developing the Capacity } \\
\text { of Faculty to Become } \\
\text { Institutional Agents for } \\
\text { Latinos in STEM. }\end{array}$ & $\begin{array}{l}\text { Individual } \\
\text { and Program } \\
\text { and } \\
\text { Institutional } \\
\text { (Research } \\
\text { Universities) }\end{array}$ & $\begin{array}{l}\text { Profiles of a dean (Armando } \\
\text { Gomez) and a professor (David } \\
\text { Ramirez) depicting how } \\
\text { institutional agents use their } \\
\text { knowledge, networks, and } \\
\text { resources to assist Latino transfer } \\
\text { students in STEM programs at } \\
\text { four-year research universities. }\end{array}$ & $\begin{array}{l}\text { CUE Report: Bensimon, } \\
\text { E.M. \& Dowd, A.C. (2012). }\end{array}$ \\
\hline
\end{tabular}

${ }^{9}$ Click on the text in the first column for hyperlinks to PDF documents and related content on the Center for Urban Education (CUE) web site (http://cue.usc.edu/). 


\begin{tabular}{|c|c|c|c|}
\hline Inquiry Tool $^{10}$ & $\begin{array}{l}\text { Reflective } \\
\text { Practice } \\
\text { Supported at } \\
\text { the Level of } \\
\text { the: }\end{array}$ & Topical Focus & Format \\
\hline \multicolumn{4}{|c|}{ II. CUE Published Reports with Data Tools and Narrative Profiles } \\
\hline $\begin{array}{l}\text { Tapping HSI-STEM } \\
\text { Funds to Improve Latina } \\
\text { and Latino Access to the } \\
\text { STEM Professions. }\end{array}$ & $\begin{array}{l}\text { Individual } \\
\text { and } \\
\text { Administrativ } \\
\text { e (financial } \\
\text { aid programs) }\end{array}$ & $\begin{array}{l}\text { Statistical summaries of college } \\
\text { financing strategies of Latinos } \\
\text { who earned STEM bachelor's } \\
\text { degrees; profiles of three students } \\
\text { (Armando Garcia, Laura } \\
\text { Montero, and Ivette Torrres) } \\
\text { depicting the support they } \\
\text { received from financial aid and } \\
\text { institutional agents. }\end{array}$ & $\begin{array}{l}\text { CUE Report: Malcom L.E., } \\
\text { Dowd, A.C., \& Yu, T. } \\
\text { (2010). }\end{array}$ \\
\hline $\begin{array}{l}\text { Benchmarking the } \\
\text { Success of Latino and } \\
\text { Latina Students in STEM } \\
\text { to Achieve National } \\
\text { Graduation Goals. }\end{array}$ & $\begin{array}{l}\text { Institutional } \\
\text { Level }\end{array}$ & $\begin{array}{l}\text { Performance benchmarking } \\
\text { models and methods for using } \\
\text { numerical college data for inquiry. }\end{array}$ & $\begin{array}{l}\text { CUE Report: Dowd, A.C., } \\
\text { Malcom, L.E., \& Bensimon, } \\
\text { E.M. (2009). }\end{array}$ \\
\hline \multicolumn{4}{|c|}{$\begin{array}{c}\text { III. STEM Toolkit: Tools for Increasing Latina and Latino STEM Baccalaureates } \\
\end{array}$} \\
\hline $\begin{array}{l}\text { Institutional Agents: } \\
\text { What They Do }\end{array}$ & Individual & $\begin{array}{l}\text { The roles and characteristics of } \\
\text { institutional agents identified by } \\
\text { Stanton-Salazar (2011) }\end{array}$ & $\begin{array}{l}\text { At-a-glance summary of } \\
\text { behaviors associated with } \\
\text { each role. }\end{array}$ \\
\hline $\begin{array}{l}\text { Institutional Agents in } \\
\text { Action: } \\
\text { Manuel Diaz: Bridging } \\
\underline{\text { Success }} \underline{\text { Reflection, }} \\
\underline{\text { Analysis }} \\
\underline{\text { Raymond Huerta: }} \\
\underline{\text { Overcoming Resistance }} \\
\underline{\text { Reflection, }} \underline{\text { Analysis }} \\
\underline{\text { Armando Gomez: }} \\
\underline{\text { Exercising Leadership }} \\
\underline{\text { Reflection, }} \underline{\text { Analysis }} \\
\underline{\text { Sarah Gardner: }} \\
\underline{\text { Navigating the System }} \\
\underline{\text { Reflection }}, \underline{\text { Analysis }}\end{array}$ & $\begin{array}{l}\text { Individual } \\
\text { and } \\
\text { Institutional }\end{array}$ & $\begin{array}{l}\text { Recruitment, advising, } \\
\text { assessment, and admissions at } \\
\text { four-year universities to make } \\
\text { them more inclusive of Latinos; } \\
\text { Counseling and financial aid } \\
\text { advising at universities and } \\
\text { community colleges; } \\
\text { Program development and } \\
\text { networking; } \\
\text { Systemic change. }\end{array}$ & $\begin{array}{l}\text { Narrative profiles of } \\
\text { institutional agents, each } \\
\text { accompanied by a } \\
\text { worksheet for Reflection } \\
\text { Exercises and Academic } \\
\text { Analyses (applying the } \\
\text { typology of Stanton- } \\
\text { Salazar's } 14 \text { institutional } \\
\text { agents' roles). }\end{array}$ \\
\hline
\end{tabular}

${ }^{10}$ Click on the text in the first column for hyperlinks to PDF documents and related content on the Center for Urban Education (CUE) web site (http://cue.usc.edu/). 


\begin{tabular}{|c|c|c|c|}
\hline Inquiry Tool ${ }^{11}$ & $\begin{array}{l}\text { Reflective } \\
\text { Practice } \\
\text { Supported at } \\
\text { the Level of } \\
\text { the: }\end{array}$ & Topical Focus & Format \\
\hline \multicolumn{4}{|c|}{ III. STEM Toolkit: Tools for Increasing Latina and Latino STEM Baccalaureates } \\
\hline $\begin{array}{l}\text { Maria Mendoza: Creating } \\
\text { Pathways } \\
\text { Reflection, Analysis } \\
\text { Ana Navarro: Financing } \\
\underline{\text { Futures }} \\
\text { Reflection, Analysis }\end{array}$ & & & \\
\hline $\begin{array}{l}\text { Institutional Agent Self- } \\
\text { Assessment }\end{array}$ & Individual & $\begin{array}{l}\text { Roles, behaviors and } \\
\text { characteristics of Stanton- } \\
\text { Salazar's (2011) 14-category } \\
\text { institutional agent typology }\end{array}$ & $\begin{array}{l}\text { Self-assessment inventory } \\
\text { with indicators based on } \\
\text { institutional agent roles, } \\
\text { behavioral frequency } \\
\text { response scales, and open- } \\
\text { ended prompts for } \\
\text { reflection. }\end{array}$ \\
\hline $\begin{array}{l}\text { Leader Self-Assessment } \\
\text { Inventory }\end{array}$ & Individual & $\begin{array}{l}\text { (1) Use of data; } \\
\text { (2) The role of faculty; } \\
\text { (3) Use of collaborations; } \\
\text { (4) Community college } \\
\text { partnerships; } \\
\text { (5) Graduate school and career } \\
\text { planning. }\end{array}$ & $\begin{array}{l}\text { Self-assessment inventory } \\
\text { with indicators grouped in } \\
\text { the five categories of topical } \\
\text { focus with binary (yes/no) } \\
\text { behavioral response scales } \\
\text { and open-ended prompts } \\
\text { for reflection. }\end{array}$ \\
\hline $\begin{array}{l}\text { Team Self-Assessment } \\
\text { Inventory }\end{array}$ & $\begin{array}{l}\text { Group, } \\
\text { Committee, } \\
\text { Program, or } \\
\text { Department }\end{array}$ & $\begin{array}{l}\text { (1) Use of data; } \\
\text { (2) Campus resources; } \\
\text { (3) Community college transfer; } \\
\text { (4) Research and funding } \\
\text { opportunities; } \\
\text { (5) Academic/career advising and } \\
\text { graduate admissions. }\end{array}$ & $\begin{array}{l}\text { Self-assessment inventory } \\
\text { with indicators grouped in } \\
\text { the four categories of } \\
\text { topical focus with binary } \\
\text { (yes/no) behavioral } \\
\text { response scales and open- } \\
\text { ended prompts for } \\
\text { reflection. }\end{array}$ \\
\hline
\end{tabular}

The Missing '87 project at LBCC. The Transfer SAI-Two-Year College Version was subsequently pilot tested and further developed at Long Beach City College (LBCC) in the spring of 2007. Approximately twenty LBCC faculty, counselors, and administrators collaborated with CUE researchers in two teams to conduct inquiry (for details, see Bensimon \& Dowd, 2009; Bensimon et al., 2007; Dowd, 2010; Dowd et al., 2011). One group interviewed students who were eligible to transfer but who chose not to. The interview protocol drew our understanding of the importance of institutional agents in empowering students' development of a collegiate identity (for more information, see Bensimon \& Dowd, 2009). Another group gathered non-intrusive observational data and conducted peer interviews with colleagues. Those colleagues interviewed held roles and responsibilities highlighted in the life history narrative analysis reported above and by our case study of exemplary practices as important to providing transfer access (for example, the roles of financial

${ }^{11}$ Click on the text in the first column for hyperlinks to PDF documents and related content on the Center for Urban Education (CUE) web site (http://cue.usc.edu/). 
aid counselor and transfer counselor). This second group of participants in our LBCC action research project used the Transfer SAI-Two-Year College Version (SAI) to guide their data collection (slightly revised to incorporate attention to transfer to non-selective universities and reformatted for web-based data entry). We have previously reported the process and outcomes of this project and the SAI indicators are available within the project report, Missing '87: A study of the "transfer gap" and "choice gap" (Bensimon et al., 2007, pp. 47-50)

The action research project at Long Beach City College contributed to promoting StantonSalazar's empowerment agent characteristics 1 and 2. Through analyses generated by their completion of our research center's Equity Scorecard (Bensimon \& Malcom, 2012), participants learned that only a very small proportion of LBCC's students (1.9 percent) transferred within the narrowest window considered "on time," which the group referred to as a "fast track" time frame (Bensimon et al, 2007). They also learned that some students who were eligible to transfer to one of the selective University of California campuses decided instead to transfer to a less selective institution (Bensimon \& Dowd, 2009).

By collecting observational data in transfer centers and workshops, faculty members in particular gained a stronger sense of the complexity of transfer policies, which pointed to the need to provide greater institutional support to students. They learnt that transfer requirements are difficult for students to decipher and that human resources on the campus, in terms of designated, trained transfer counselors, were not nearly adequate to meet students' needs for counseling. These findings (for more information, see Dowd et al., 2011) led to greater awareness among practitioners that lacking a greater number of counselors, faculty would need to serve as agents assisting in shaping students transfer goals, information seeking, decision-making, and transitions. Some faculty participants began to blur the norms of professional conduct in the sense that they realized a strict boundary could not be maintained between the responsibilities of classroom instructors and counselors. They began to think differently about their responsibilities towards potential transfer students and to see their own practices with new eyes. As a result, they created some structures new to their college, such as a transfer academy that would provide a "home base" for aspiring transfer students and a program where faculty could coordinate with a counselor to make time in class to discuss transfer options (Bensimon et al., 2007).

STEM Toolkit: Tools for Increasing Latina and Latino STEM Baccalaureates. We followed the LBCC action research project with another study of transfer, this time focused on transfer access to STEM bachelor's degrees for Latino community college students. Again, we produced inquiry tools as part of a mixed-methods research design. These tools are summarized in Table 3, with links to reports published by CUE (Table 3, Section II) and inquiry tools collected on our web site as the "STEM Toolkit: Tools for Increasing Latina and Latino STEM Baccalaureates" (Table 3, Section III). An at-a-glance summary of institutional agent roles and the characteristics of empowerment agents provides a quick introduction of the institutional agents conceptual framework for interested practitioners.

The results of statistical analyses showing the limited proportion of Latino transfer students who earn STEM bachelor's degrees were disseminated in two reports (Dowd, Malcom, \& Bensimon, 2009; Malcom, Dowd, \& Yu, 2010) to enable greater awareness among practitioners of

${ }^{12}$ Only 520 students out of total population of 27,422 (1.9 percent) completed transfer requirements to a UC or CSU campus within three years for the 1999-2002 cohorts studied. Among these 520 "fast-track" students, 22 percent had not transferred as of spring 2006 (Bensimon et al, 2009, p. 2). The cohort studied included those students who enrolled at LBCC for the first time during the fall semesters from 1999-2002 (p. 6). 
the problem of limited transfer access in STEM. Case studies of purposefully sampled Hispanic Serving Institutions provided the basis for understanding the state of awareness and agency among STEM practitioners around the issue of Latino underrepresentation in STEM. The statistical and case study results were disseminated in four public reports that included profiles in narrative form and models for the use of numerical college data for inquiry (Bensimon \& Dowd, 2012; Bensimon et al. 2012, Malcom, Dowd, \& Yu, 2010). Six profiles of institutional agents do not appear in published reports but are included in the STEM toolkit on our web site (see Table 3, Section III). These profiles, in addition to addressing functional areas mentioned above, also model alternatives for the practices of recruitment, advising, assessment, and admissions to make them more inclusive of Latinos:

The profiles serve as prompts for inquiry about institutional practice. They depict practitioners acting as institutional agents by providing direct and integrative support to Latino students and by networking with colleagues to increase the resources available to expand STEM transfer access, for example through program development or new recruiting practices. The profiles illustrate the behaviors of agents who create new programs, assist students with financial aid, negotiate with colleagues to obtain greater resources for low-status students, and develop a more culturally responsive pedagogy in STEM classrooms and programs. These tools help to develop awareness that students need institutional support (empowerment agent characteristic 2) and provide models of alternative practices intended to reduce stratification (characteristic 3 ).

Some of the profiles, such as the one of Sarah Gardner, depict institutional agents providing emotional support, encouragement, and practical guidance to Latino students, reflecting the categories of direct and integrative support. Others, such as the one of Armando Gomez, depict administrators and program directors bridging structural holes by developing cross-institution and cross-sector networks of coordinated action. These vignettes illustrate the considerable effort involved in creating networks and utilizing them to make systemic changes.

Reflecting the practices of institutional agents we observed through the case study, the profiles depict pragmatic, not radical, departures to normative practices. Yet, the vignettes relate what we learned from the case study respondents, that due to conflicts with colleagues who do not see a need for change, institutional agents become wary of carrying the mantle of the advocate for Latino students (empowerment agent characteristic 5). This hampers a practitioner's willingness to act as an empowerment agent. Similarly, policies that seem far beyond any one practitioner's control, such as those determining public tuition funding and financial aid, are a source of frustration that undermines practitioners' ideological commitments to make a positive difference in the lives of Latino students. Two profiles (Maria Mendoza and Ana Navarro) depict counselors in the midst of attempting to help Latino students who are struggling to pay for college and are giving up on graduate school plans due to lack of funding.

Just like the participants in the life story narrative analyses reported in this article, students in the profiles are working full time or stringing together multiple part time jobs. These narrative depictions are intended to promote awareness on the part of STEM practitioners on the need that Latino students have for greater institutional support (empowerment agent characteristic 2). Each profile is accompanied by a Reflection Exercise and an Academic Analysis (for hyperlinks see Table 3, Section III, column 1). The Reflection Exercise asks a practitioner to compare their practices to the "best practice" model provided in the vignette. Although the vignettes are idealized to some extent, they provide reasonable models for comparison because they are based on the work of actual case study respondents. In effect the vignettes serve as performance benchmarks. Practitioners are invited to reflect on their own practices by answering questions such as the following, which accompany the vignette of Armando Gomez: 
1. Where does Armando's commitment to increasing opportunities for Latina and Latino STEM students originate from?

2. What specific knowledge does Armando have about Latinas and Latinos in STEM fields?

3. In what ways does Armando move beyond the role of a bridging agent into an institutional broker for Latina and Latino STEM students?

4. What institutional connections and resources does Armando use to support Latina and Latino STEM students and how does he utilize his networks and resources on behalf of Latina and Latino STEM students?

5. What additional resources and networks can Armando draw upon to increase his support of Latina and Latino STEM students at his institution?

6. In what ways do you act as a bridging agent and/or institutional broker for Latina and Latino STEM students in your institution? What could you do to be a more effective bridging or institutional broker?

The final materials, beyond the reports, profiles, reflection exercises, and academic analyses discussed above, are three self-assessment inventories (SAIs) for use at the individual, group, and leadership levels. The Institutional Agent Self-Assessment has prompts based on Stanton-Salazar's description of the institutional agent roles side by side to a frequency response scale, for a respondent to reflect on how often they take certain actions on behalf of their students. For example, the first indicator is "I've been actively involved in helping a significant number of students assess problems, gather information, and make appropriate decisions related to their success within the institution and within the educational system," with behavioral response options in a five-point Likert scale spanning never, sometimes, frequently. The frequency response scale for each item is followed by three questions: (1) How do you do this? (2) What are the challenges? And (3) To what extent have you done this for your Latino students? The purpose of asking how often practitioners take steps on behalf of Latino students in particular is to direct attention to the problem of the stratification of opportunities and outcomes for Latinos in STEM, whose representation diminishes at each step of the educational hierarchy (Dowd, Malcom, \& Bensimon, 2009). STEM practitioners are apt to claim that they are "color blind" and treat all their students the same, but the pervasive exclusion of Latinos from high status STEM fields of study and occupations suggest that this approach is not effective in assisting Latino students (Bensimon \& Dowd, 2012; Chase et al, in press).

The Leader Self-Assessment Inventory and the Team Self-Assessment Inventory have similar designs, where prompts for reflection on practices are followed by response options and questions with space for notes to be made in preparation for a group discussion. For example, the Team SAI has twenty-three indicators organized into five categories (use of data, campus resources, community college transfer, research and funding opportunities, and academic/career advising and graduate admissions). Like the SAI used in the LBCC action research project, the Team SAI calls attention to the way that resources are being utilized on campus. Often practitioners believe that adequate institutional supports exist, but students are failing to take advantage of them due to lack of motivation or poor time management. The LBCC study showed that when practitioners gain first-hand knowledge of the quality of resources and the often opaque or off-putting bureaucratic processes involved in using those resources they appreciate that students require higher quality, more accessible institutional supports. This can motivate agency on the part of practitioners to make changes in their individual practices. If sufficient collective agency is generated, the changes may take place at an organizational level (Dowd, Bishop, Bensimon, \& Witham, 2011). 
Limitations. The tools described in this section were developed based on case studies that illustrated the exemplary practices of faculty and administrators who were characterized by informants at the sites as deeply involved in promoting transfer for racial-ethnic minority or lowstatus youth. These tools have not been evaluated through rigorous research designs by external evaluators. A study by Santiago (2012), in which the researcher pilot tested the Latinos in STEM SAI through a case study of six faculty members identified by students as institutional agents, provides evidence that although the faculty were caring and identified with the students' experiences in STEM, they were reluctant to take up the characteristics of an empowerment agent in a political sense. Consistent with earlier studies, these institutional agents taught students how to navigate the system, encouraged their aspirations, and provided specific guidance or assistance with academic and bureaucratic problem solving, they did so within the political economy of the existing reward structures for faculty work.

Recognizing that the inquiry tools we have developed are not a panacea, it is important to highlight that we are not making claims in regard to their effectiveness in motivating practitioners to act as institutional agents on behalf of low-status youth. We do believe that these tools contribute to a more robust conceptualization of the ways in which more commonly used strategies such as "benchmarking" and the dissemination of "best practices" can be reformulated to support practitioner learning and professional development. We also feel it is important to forward the research agenda about the role of practitioners in bringing about institutional change that may threaten their own status or authority, yet contribute to reducing social stratification. Translating our case study results into action research designs and tools for practitioner inquiry is one way of doing that.

\section{Conclusion}

Inequities in college completion in the United States can be attributed, in very broad terms, to two kinds of obstacles: inequitable structures of access to educational resources and discriminatory beliefs or stereotypes (whether based on race, ethnicity, or class) about students' abilities, academic preparation, motivation, goals, or aspirations. Inequitable structures include educational policies that put members of low socioeconomic status and non-dominant racial groups at a disadvantage when it comes to college access and completion. Examples include declining public funding for college; legacy admissions at private and public selective universities that favor the children of alumni; high stakes standardized testing that determine postsecondary placements (for which-low status students have inadequate opportunity to prepare); and lack of counseling in public schools and colleges (Grubb, 2006; Kahlenberg, 2004; Karen, 1991; Martin, Karabel, \& Jaquez, 2005).

To address inequities in postsecondary education, including inequities that limit transfer access to selective institutions and to STEM fields of study, it is necessary to reduce structural barriers and actively counter discriminatory beliefs based on race and class. This empirical study based on narrative analysis of life story interviews with 10 low-socioeconomic-status students who successfully transferred from a community college to a selective liberal arts college or university illustrates what it means for individual faculty members and academic administrators to act as institutional agents on behalf of low-status college students. The study participants were purposefully sampled to examine the role of institutional agents in supporting the successful educational transitions of transfer students. The findings contribute to our understanding of how low-status students navigate other postsecondary transitions as well.

The results show that institutional agents provide students who are challenged by a difficult educational transition with a secure base, in a psychological sense, allowing them to move from a 
physical milieu in which they are comfortable to one that is unfamiliar and intimidating. The students' growth is observed through their ability to take specific actions necessary to accomplish the educational transition of transfer as well as through their articulation of a new, acquired identity as an elite college student. As illustrated in the findings, a student experiencing this identity development is supported by the psychological validation of the institutional agent, as well as by the agent's personal and positional resources. Most critically, by providing a secure base for psychological development, institutional agents enable low-status students to take advantage of resources available in the collegiate environment (e.g. information, financial aid, transfer advising sessions) that are instrumental to their success. Through the experience of psychological validation in the relationship with the institutional agent, students gain the confidence to acquire and act on educational resources.

The findings also point to the limitations of the current ways college practitioners manifest their roles as institutional agents. Stanton-Salazar (2011) asserts that institutional agents who aide individual status attainment are not acting to empower low-status students and groups unless they foster a critical consciousness in themselves and their students to change the system of educational stratification which is emblemized by the transfer function.

At several of the four-year institutions, there were distinct programs and practices to address transfer students' academic needs and prepare them for the socio-cultural barriers that divide the world of open access and selective institutions. Program personnel supported students through their initial periods of self-doubt and difficulty in adjusting to their new environments. Thus, the results show the value of special programs for transfer students at four-year colleges and universities, particularly those that have their own physical space and provide a venue for students to find a safe haven and have proximity to trusted advisors, both of which are important factors to provide students with the support to engage in exploration, risk taking and self-development (Ainsworth, 1991; Doherty \& Feeney, 2004). However, it is important to note that special programs in the absence of institutional agents are unlikely to provide the same type of home base for transfer students.

Furthermore, the findings reported here indicate that adults in positions of authority in educational settings may play a unique and essential role in the experience of psychological validation low-status students require for collegiate identity development. This is an important point because it implies a particular role for faculty and high-level administrators that cannot be fulfilled by peer counselors or professional counselors in marginalized special programs. In this respect, our results show that peer counseling and special programs are likely to be inadequate interventions to address inequities in postsecondary education. This implies that faculty members and others in positions of authority need to become personally involved in advising low-status students and that the complete outsourcing of advising functions to narrowly defined technical positions or to computerized information systems will be ineffective in producing greater equity or efficiency in transfer functions.

\section{References}

American Association of Community Colleges (AACC). (2012, April). Reclaiming the American dream: A report from the 21st century commission on the future of community colleges. Washington, DC:

American Association of Community Colleges. Retrieved from

http://www.aacc.nche.edu/aboutcc/21stcenturyreport/21stCenturyReport.pdf. 
Anderson, G. M., Alfonso, M., \& Sun, J. C. (2006). Rethinking cooling out at public community colleges: An examination of fiscal and demographic trends in higher education and the rise of statewide articulation agreements. Teachers College Record, 108(3), 422-451.

Anderson, G. M., Sun, J. C., \& Alfonso, M. (2006). Effectiveness of statewide articulation agreements on the probability of transfer: A preliminary policy analysis. Review of Higher Education, 29(3), 261-291.

Ainsworth, M. D. S. (1991). Attachment and other affectional bonds across the life cycle. In C.

M. Parkes, J. Stevenson-Hinde, \& P. Marris (Eds.), Attachment across the life cycle (pp. 33-51). New York: Routledge.

Barron's profiles of American colleges. (2003, 2005). Hauppauge, N.Y: Barron's Educational Series, Inc.

Bender, B. E., \& Schuh, J. H. (Eds.). (2002). Using benchmarking to inform practice in higher education (Summer 2002 ed. Vol. 118). San Francisco: Jossey Bass.

Bensimon, E. M. (2007). The underestimated significance of practitioner knowledge in the scholarship of student success. Review of Higher Education, 30(4), 441-469.

Bensimon, E. M., \& Dowd, A. C. (2009). Dimensions of the "transfer choice" gap: Experiences of Latina and Latino students who navigated transfer pathways. Harvard Educational Review (Winter), 632-658.

Bensimon, E. M., \& Dowd, A. C. (2012). Developing the capacity of faculty to become Institutional Agents for Latinos in STEM. Los Angeles, CA: University of Southern California.

Bensimon, E. M., Dowd, A. C., Alford, H., \& Trapp, F. (2007). Missing 87: A study of the "transfer gap" and "choice gap". Long Beach and Los Angeles: Long Beach City College and the Center for Urban Education, University of Southern California.

Bensimon, E. M., Dowd, A. C., Chase, M. M., Sawatzky, M., Shieh, L. T., Rall, R. M., et al. (2012). Community college change agents at HSIs: Stewarding HSI-STEM funds for Latino student success in STEM. Los Angeles, CA: University of Southern California.

Bensimon, E. M., \& Malcom, L. (2012). Confronting equity issues on campus: Implementing the Equity Scorecard in theory and practice. Sterling, VA: Stylus Publishing.

Bensimon, E. M., Polkinghorne, D. E., Bauman, G. L., \& Vallejo, E. (2004). Doing research that makes a difference. Journal of Higher Education, 75(1), 104-126.

Bowlby, J. (1982). Attachment and loss: Vol. 1. Attachment (2 ${ }^{\text {nd }}$ ed.). New York: Basic Books.

Bowlby, J. (1973). Attachment and loss: Vol. 2. Separation. New York, NY: Basic Books.

Bowlby, J. (1980). Attachment and loss: Vol. 3. Loss, sadness and depression. New York, NY: Basic Books.

Bowlby, J. (1979). The making \& breaking of affectional bonds. New York: Routledge.

Bowlby, J. (1988). A secure base: Parent-child attachment and healthy buman development. New York, NY: Basic Books.

Brint, S. \& J. Karabel (1989). The diverted dream: Community colleges and the promise of educational opportunity in America, 1900-1985. New York: Oxford University Press.

California Community Colleges Chancellor's Office. (n.d.). Extended Opportunity Programs and Services (EOPS). Retrieved from http://extranet.cccco.edu/Divisions/StudentServices/EOPS.aspx.

Cejda, B. D., Casparis, C. A., Rhodes, J. H., \& Kelly, S.-N. (2008). The role of social capital in the educational decisions of Hispanic students attending Hispanic-serving community colleges. Enrollment Management Journal, 2(1), 32-59.

Chase, M. M., Bensimon, E. M., Shieh, L. T., Jones, T., \& Dowd, A. C. (in press). Constraints and opportunities for practitioner agency in STEM programs in Hispanic serving community colleges. In R. T. Palmer \& J. L. Wood (Eds.), Community colleges and racial minorities in STEM. New York: Routledge. 
Crossley, M. L. (2000). Introducing narrative psychology: Self, trauma, and the construction of meaning. Buckingham: Open University Press.

Doerfel, M. L., \& Ruben, B. D. (2002). Developing more adaptive, innovative, and interactive organizations. In B. E. Bender \& J. H. Schuh (Eds.), Using benchmarking to inform practices in higher education (Summer 2002 ed., Vol. 118). San Francisco: Jossey Bass.

Dougherty, K. J. (1994). The contradictory college: The conflicting origins, impacts, and futures of the community college. Albany, NY: State University of New York Press.

Doherty, N. A., \& Feeney, J. A. (2004). The composition of attachment networks throughout the adult years. Personal Relationships, 11, 469-488.

Dowd, A. C. (2008). The community college as gateway and gatekeeper: Moving beyond the access "saga" to outcome equity. Harvard Educational Review, 77(4), 407-419.

Dowd, A. C. (2010). Improving transfer access for low-income community college students. In A. Kezar (Ed.), Recognizing and serving low-income students in postsecondary education: An examination of institutional policies, practices, and culture (pp. 217-231). New York, NY: Routledge.

Dowd, A. C., Bensimon, E. M., Gabbard, G., Singleton, S., Macias, E. E., Dee, J., et al. (2006). Transfer access to elite colleges and universities in the United States: Threading the needle of the American dream. Lansdowne; VA: Jack Kent Cooke Foundation.

Dowd, A. C., Bishop, R., Bensimon, E. M., \& Witham, K. (2011). Accountability for equity in postsecondary education. In K. S. Gallagher, R. Goodyear, D. J. Brewer \& R. Rueda (Eds.), Urban education: A model for leadership and policy (pp. 170-185). New York: Routledge.

Dowd, A. C., Cheslock, J. J., \& Melguizo, T. (2008). Transfer access from community colleges and the distribution of elite higher education. Journal of Higher Education, 79(4), 442-472.

Dowd, A. C., \& Malcom, L. E. (2012). Reducing undergraduate debt to increase Latina and Latino participation in STEM professions. Los Angeles, CA: University of Southern California.

Dowd, A. C., Malcom, L. E., \& Bensimon, E. M. (2009). Benchmarking the success of Latina and Latino students in STEM to achieve national graduation goals. Los Angeles: Center for Urban Education, University of Southern California.

Dowd, A. C., Malcom, L. E., \& Macias, E. E. (2010). Improving transfer access to STEM bachelor's degrees at Hispanic Serving Institutions through the America COMPETES Act. Los Angeles, CA: Center for Urban Education, University of Southern California.

Dowd, A. C., \& Melguizo, T. (2008). Socioeconomic stratification of community college transfer access in the 1980s and 1990s: Evidence from HS\&B and NELS. Review of Higher Education, 31(4), 377-400

Dowd, A. C., M. Sawatzky, et al. (2011). Theoretical foundations and a research agenda to validate measures of intercultural effort. Review of Higher Education, 35(1), 17-44.

Dowd, A. C., Sawatzky, M., Rall, R. M., \& Bensimon, E. M. (in press). Action research: An essential practice for Twenty-First Century assessment. In R. T. Palmer, D. C. Maramba \& M. Gasman (Eds.), Fostering success of ethnic and racial minorities in STEM: The role of Minority Serving Institutions. New York: Routledge.

Dowd, A. C., \& Tong, V. P. (2007). Accountability, assessment, and the scholarship of "best practice". In J. C. Smart (Ed.), Handbook of Higher Education (Vol. 22, pp. 57-119). Springer Publishing.

Engeström, Y. (2010). Expansive learning at work: Toward an activity theoretical reconceptualization. Journal of Education and Work, 14(1), 133-156.

Fishbein, M. (2000). The role of theory in HIV prevention. AIDS Care, 12(3), 273-278.

Fishbein, M., \& Ajzen, I. (2010). Predicting and changing behavior: The reasoned action approach. New York: Psychology Press. 
Fishbein, M., Hennessy, M., Yzer, M., \& Douglas, J. (2003). Can we explain why some people do and some people do not act on their intentions? Psychology, Health, and Medicine, 8(1), 3-18.

Gabbard, G., Singleton, S., Macias, E. E., Dee, J., Bensimon, E. M., Dowd, A. C., et al. (2006). Practices supporting transfer of low-income community college transfer students to selective institutions: Case study findings. Boston, MA and Los Angeles, CA: University of Massachusetts Boston and University of Southern California.

González, K. P., Stone, C., \& Jovel, J. E. (2003). Examining the role of social capital in access to college for Latinas: Toward a college opportunity framework. Journal of Hispanic Higher Education, 2(1), 146-170.

Greenwood, D. J., \& Levin, M. (1998). The friendly outsider: Knowledge and skills in action Introduction to action research (pp. 93-127). Thousand Oaks, CA: Sage Publications.

Greenwood, D. J., \& Levin, M. (2005). Reform of the social sciences and of universities through action research. In N. K. Denzin \& Y. S. Lincoln (Eds.), The Sage Handbook of Qualitative Research (pp. 43-64). Thousand Oaks, CA: Sage Publications.

Grubb, W. N. (2006). "Like, what do I do now?" The dilemmas of guidance counseling. In T. Bailey \& V. Smith Morest (Eds.), Defending the community college equity agenda (pp. 195-222). Baltimore, MD: Johns Hopkins University Press.

Guiffrida, D. A. (2009). Theories of human development that enhance an understanding of the college transition process. Teachers College Record, 111(10), 2419-2443.

Handel, S. J., \& Williams, R. A. (2012). The promise of the transfer pathway: Opportunity and challenge for community college students seeking the baccalaureate degree. New York, NY: College Board Advocacy \& Policy Center. Retrieved from http://advocacy.collegeboard.org/sites/default/files/community-college-transferpathway-summary-5938.pdf.

Harper, S. R. (2012). Race without racism: How higher education researchers minimize racist institutional norms. Review of Higher Education, 36(1), 9-29.

Hurtado, S., \& Carter, D. F. (1997). Effects of college transition and perceptions of the campus racial climate on Latino college students' sense of belonging. Sociology of Education, 70(4), 324345.

Hurtado, S., Eagan, M. K., Tran, M. C., Newman, C. B., Chang, M. J., \& Velasco, P. (2011). “We do science here": Underrepresented students' interaction with faculty in different college contexts. Journal of Social Issues, 67(3), 553-579.

Kahlenberg, R. D. (2004). America's untapped resource: low-income students in higher education. New York, NY: Century Foundation Press.

Karen, D. (1991). The politics of class, race, and gender: Access to higher education in the United States, 1960-1986. American Journal of Education, 99(2), 208-237.

Kemmis, S., \& McTaggart, R. (2000). Participatory action research. In N. K. Denzin \& Y. S. Lincoln (Eds.), Handbook of qualitative research (2nd ed., pp. 567-605). Thousand Oaks, CA: Sage Publications.

Kemmis, S., \& McTaggart, R. (2005). Participatory action research: Communicative action and the public sphere. In N. K. Denzin. \& Y. S. Lincoln (Eds.), Handbook of Qualitative Research (3 ${ }^{\text {rd }}$ edition, pp.559-603). Thousand Oaks, CA: Sage Publications.

Kenny, M. E. (1987). The extent and function of parental attachment among first-year college students. Journal of Youth and Adolescence, 16, 17-27.

Malcom, L. E. (2008). Accumulating (dis)Advantage? Institutional and financial aid pathways of Latino STEM baccalaureates. Unpublished dissertation, University of Southern California, Los Angeles.

Malcom, L. E., \& Dowd, A. C. (2012). The impact of undergraduate debt on the graduate school enrollment of STEM baccalaureates. Review of Higher Education, 35(2), 265-305. 
Malcom, L. E., Dowd, A. C., \& Yu, T. (2010). Tapping HSI-STEM funds to improve Latina and Latino access to STEM professions. Los Angeles, CA: University of Southern California.

Martin, I., Karabel, J., \& Jaquez, S. W. (2005). High school segregation and access to the University of California. Educational Policy, 19(2), 308-330.

Melguizo, T., \& Dowd, A. C. (2009). Baccalaureate success of transfers and rising four-year college juniors. Teachers College Record, 111(1), 55-89.

Melguizo, T., Kienzl, G. S., \& Alfonso, M. (2011). Comparing the educational attainment of community college transfer students and four-year college rising juniors using propensity score matching methods. Journal of Higher Education, 82(3), 266-291.

Merriam, S. B. (1988). Case study research in education: A qualitative approach. San Francisco, CA: JosseyBass Publishers.

Museus, S. D., \& Maramba, D. C. (2011). The impact of culture on Filipino American students' sense of belonging. The Review of Higher Education, 34(2), 231-258.

Museus, S. D., \& Neville, K. M. (2012). Delineating the ways that key institutional agents provide racial minority students with access to social capital in college. Journal of College Student Development, 53(3), 436-452.

Museus, S. D., \& Quaye, S. J. (2009). Toward an intercultural perspective of racial and ethnic minority college student persistence. Review of Higher Education, 33(1), 67-94.

National Center for Educational Statistics (NCES) (2011). Commmunity college outcomes: 1994-2009 (NCES Web Table 2012-253). Washington, DC: U.S. Department of Education.

Noffke, S. E. (1997). Professional, personal, and political dimensions of action research. Review of Educational Research, 22, 305-343.

Nora, A. (1990). Campus aid programs as determinants of retention among Hispanic community college students. Journal of Higher Education, 61(3), 312-331.

Nora, A., Cabrera, A. F., Hagedorn, L. S., \& Pascarella, E. (1996). Differential impacts of academic and social experiences on college-related behavioral outcomes across different ethnic and gender groups at four-year institutions. Research in Higher Education, 37(4), 427-451.

Pak, J. (2006). Korean American women: Stories of acculturation and changing selves. New York: Routledge.

Packard, B. W.-L. (2011). Effective outreach, recruitment, and mentoring into STEM pathways: Strengthening partnerships with community colleges. Paper presented at the Community Colleges in the Evolving STEM Education Landscape, Washington, D.C.

Packard, B. W.-L., Gagnon, J. L., LaBelle, O., Jeffers, K., \& Lynn, E. (2011). Women's experiences in the STEM community college transfer pathway. Journal of Women and Minorities in Science and Engineering, 17(2), 129-147.

Palladino-Schultheiss, D. E., \& Blustein, D. L. (1994). Role of adolescent-parent relationship in college students development and adjustment. Journal of Counseling Psychology, 41, 248-255.

Patton, M. Q. (1990). Qualitative evaluation and research methods ( $2^{\text {nd }}$ edition). Newbury Park, CA: Sage Publications.

Pistole, M. C. (1989). Attachment: Implications for counselors. Journal of Counseling and Development, 68, 190-193.

Polkinghorne, D. E. (1995). Narrative configuration in qualitative analysis. International Journal of Qualitative Studies in Education, 8(1), 8-25.

Polkinghorne, D. E. (2004). Practice and the human sciences: The case for a judgment-based practice of care. Albany: State University of New York Press.

Puente. (n.d.). About Puente. Retrieved from www.puente.net/about.

Reason, P. (1994). Three approaches to participative inquiry. In N. K. Denzin \& Y. S. Lincoln (Eds.), Handbook of qualitative research (pp. 324-339). Thousand Oaks: Sage Publications. 
Rendón, L. I. (1993). Validating culturally diverse students: Towards a new model of learning and student development. University Park, PA: National Center on Postsecondary Teaching, Learning, and Assessment.

Rendón, L. I. (1994). Beyond involvement: Creating validating academic and social communities in the community college.

Rendón, L. I., Jalomo, R. E., \& Nora, A. (2000). Theoretical considerations in the study of minority student retention in higher education. In J. M. Braxton (Ed.), Reworking the student departure puzzle (pp. 127-156). Nashville: Vanderbilt University Press.

Rice, K. G., Cunningham, T. J., \& Young, M. B. (1997). Attachment to parents, social competence, and emotional well-being: A comparison of Black and White late adolescents. Journal of Counseling Psychology, 44, 89-101.

Santiago, C. (2012). Faculty as institutional agents for low-income Latino students in science, technology, engineering, and mathematics fields at a Hispanic-Serving Institution (Unpublished doctoral dissertation). University of Southern California, Los Angeles, CA.

Schein, E. H. (1991). Organizational culture and leadership. San Francisco: Jossey-Bass Publishers.

Seo, M. G., \& Creed, W. E. D. (2002). Institutional contradictions, praxis, and institutional change: A dialectical perspective. Academy of Management Review, 27(2), 222-247.

Seybert, J. A. (2004, June 1). Two national community college benchmarking projects: Progress and status. Paper presented at the Association for Institutional Research, Boston, MA.

Soucy, N. \& Larose, S. (2000). Attachment \& control in family and mentoring contexts as determinants of adolescent adjustment to college. Journal of Family Psychology, 14(1), 125-143.

Stake, R. E. (1995). The art of case study research. Thousand Oaks, CA: Sage Publications.

Stanton-Salazar, R. D. (1997). A social capital framework for understanding the socialization of racial minority children and youths. Harvard Educational Review, 67(1), 1-40.

Stanton-Salazar, R. D. (2001). Manufacturing hope and despair : the school and kin support networks of U.S.Mexican youth. New York: Teachers College Press.

Stanton-Salazar, R. D. (2011). A social capital framework for the study of institutional agents and their role in the empowerment of low-status youth. Youth \& Society, 43(3), 1066-1109.

Tanaka, G. (2000). Building an intercultural campus. Unpublished manuscript, Pasadena, CA.

Teranishi, R., \& Briscoe, K. (2006). Social capital and racial stratification in higher education. In J. C. Smart \& M. B. Paulsen (Eds.), Higher Education: Handbook of Theory and Research (Vol. 21, pp. 591-614): Springer.

Tierney, W. G. (1992). An anthropological analysis of student participation in college. Journal of Higher Education, 63(6), 603-618.

Tinto, V. (1975). Dropout from higher education: A theoretical synthesis of recent research. Review of Educational Research, 45(1), 89-125.

Trent, W. T., Lee, H. S., \& Owens-Nicholson, D. (2006). Perceptions of financial aid among students of color: Examining the role(s) of self-concept, locus of control, and expectations. American Behavioral Scientist, 49 (12), 1739-1759.

Valenzuela, A. (1999). Subtractive schooling. New York: SUNY Press.

Witham, K., \& Bensimon, E. M. (2012). Creating a culture of inquiry around equity and student success. In S. D. Museus \& U. M. Jayakumar (Eds.), Creating campus cultures: Fostering success among racially diverse student populations. New York: Routledge. 


\section{About the Authors}

Dr. Alicia C. Dowd

University of Southern California

Email: adowd@usc.edu

Alicia C. Dowd is co-director of the Center for Urban Education at the University of Southern

California, where she is an Associate Professor at the Rossier School of Education. Her research concerns the political economy of education with a focus on accountability for racial-ethnic equity in postsecondary participation and outcomes.

Dr. Jenny H. Pak

Biola University

Email: jenny.pak@biola.edu

Jenny H. Pak is an Associate Professor at Biola University, Rosemead School of Psychology.

She holds a doctoral degree from the University of Southern California and her area of research focuses on narrative analysis, culture, and ethnic identity development.

Dr. Estela Mara Bensimon

University of Southern California

Email: bensimon@usc.edu

Estela Mara Bensimon is co-director of the Center for Urban Education at the University of Southern California, where she is a Professor at the Rossier School of Education. Her current research is on issues of racial equity in higher education from the perspective of organizational learning and socio-cultural practice theories. She is particularly interested in place-based, practitioner-driven inquiry as a means of organizational change in higher education.

\section{Acknowledgements}

The authors wish to acknowledge the many individuals who contributed to the studies described in this article. Dr. Ricardo Stanton-Salazar consulted with us on the development of the STEM Toolkit, particularly those tools that utilize indicators based on his typology of institutional agents. Several doctoral students at the Rossier School of Education assisted with the case study data collection for the study of transfer to selective institutions, including Lindsey E. Malcom, Amalia Márquez, and Daniel K. Park. During the editing of this article, Dr. Cecilia Santiago-González provided valuable research and editing assistance, and she wrote several of the Academic Analyses of the STEM Toolkit. Last, but in no way least, Emily Ogle, the communications manager for the Center for Urban Education (CUE), wrote the profiles and web site text for CUE's STEM Toolkit based on her participation in our lengthy data analysis and research team meetings. We would also like to thank the National Science Foundation and the philanthropic foundations that provided financial support for these studies: the Jack Kent Cooke Foundation, Lumina Foundation for Education, the Nellie Mae Education Foundation, and the William and Flora Hewlett Foundation. 


\section{About the Guest Editors}

Guest Editor

Dr. Jeanne M. Powers

Associate Professor

Mary Lou Fulton Teachers College

Arizona State University

jeanne.powers@asu.edu

Dr. Powers received her Ph.D. in Sociology from the University of California, San Diego. Her research focuses on school choice, accountability policies, school finance litigation, and school segregation. Her book, Charter Schools: Reform Imagery, Reform Reality, was published in June 2009 by Palgrave Macmillan. One of Dr. Powers' ongoing projects is a historical analysis of Mexican American school segregation cases in the Southwest. For an example of this line of research, see, "Between Mendez and Brown: Gonzales v. Sheely (1951) and the Legal Campaign Against Segregation" (with Lirio Patton), an analysis of the legal arguments in Mexican American school segregation cases, which was published in March 2008 in Law and Social Inquiry. In another line of research she is examining how social science research shapes judicial decisionmaking in school finance cases. Dr. Powers' research has also been published in American Educational Research Journal, Educational Policy, and Equity and Excellence in Education. Dr. Powers is currently an Associate Editor of Education Policy Analysis Archives.

Amelia M. Topper

Doctoral Student, Education Policy and Evaluation

Mary Lou Fulton Teachers College

Arizona State University

amy.topper@asu.edu

Ms. Topper has worked in the education sector for over 15 years as both an educator and researcher, and is currently pursuing a Ph.D. in Education Policy and Evaluation at Arizona State University. Ms. Topper has experience working on studies for the U.S. Department of Education, the Lumina Foundation, the Bill \& Melinda Gates Foundation, the Pell Institute, state agencies, and local school districts. She works with Achieving the Dream, a national community college reform movement, and has authored and co-authored numerous policy briefs on the initiative-wide database. Topics of research include postsecondary student access, persistence and retention; financial aid policies; community colleges; and, K-12 student migration and charter school enrollment. Ms. Topper's research has been published in Review of Education Research, Journal of School Choice, and On the Horizon, and she is currently a Managing Editor of Education Policy Analysis Archives. She holds a Master's in Leadership in Teaching from the College of Notre Dame of Maryland, and a Bachelor's in the Philosophy and Classical Languages from St. John's College, Annapolis, Maryland. 


\section{SPECIAL ISSUE \\ The American Community College in the $21^{\text {st }}$ Century education policy analysis archives}

\section{@}

SOMRERIGHISRESERVED Readers are free to copy, display, and distribute this article, as long as the work is attributed to the author(s) and Education Policy Analysis Archives, it is distributed for noncommercial purposes only, and no alteration or transformation is made in the work. More details of this Creative Commons license are available at http://creativecommons.org/licenses/by-nc-sa/3.0/. All other uses must be approved by the author(s) or EPAA. EPAA is published by the Mary Lou Fulton Institute and Graduate School of Education at Arizona State University Articles are indexed in CIRC (Clasificación Integrada de Revistas Científicas, Spain), DIALNET (Spain), Directory of Open Access Journals, EBSCO Education Research Complete, ERIC, Education Full Text (H.W. Wilson), QUALIS A2 (Brazil), SCImago Journal Rank; SCOPUS, SOCOLAR (China).

Please contribute commentaries at http://epaa.info/wordpress/ and send errata notes to Gustavo E. Fischman fischman@asu.edu

Join EPAA's Facebook community at https://www.facebook.com/EPAAAAPE, Twitter feed @epaa_aape, and Academia.edu page at: http://asu.academia.edu/EPAAAAPE 


\section{education policy analysis archives editorial board}

Editor Gustavo E. Fischman (Arizona State University)

Associate Editors: David R. Garcia (Arizona State University), Stephen Lawton (Arizona State University)

Rick Mintrop, (University of California, Berkeley) Jeanne M. Powers (Arizona State University)

Jessica Allen University of Colorado, Boulder

Gary Anderson New York University

Michael W. Apple University of Wisconsin, Madison

Angela Arzubiaga Arizona State University

David C. Berliner Arizona State University

Robert Bickel Marshall University

Henry Braun Boston College

Eric Camburn University of Wisconsin, Madison

Wendy C. Chi* University of Colorado, Boulder

Casey Cobb University of Connecticut

Arnold Danzig Arizona State University

Antonia Darder University of Illinois, UrbanaChampaign

Linda Darling-Hammond Stanford University

Chad d'Entremont Strategies for Children

John Diamond Harvard University

Tara Donahue Learning Point Associates

Sherman Dorn University of South Florida

Christopher Joseph Frey Bowling Green State University

Melissa Lynn Freeman* Adams State College

Amy Garrett Dikkers University of Minnesota

Gene V Glass Arizona State University

Ronald Glass University of California, Santa Cruz

Harvey Goldstein Bristol University

Jacob P. K. Gross Indiana University

Eric M. Haas WestEd

Kimberly Joy Howard* University of Southern California

Aimee Howley Ohio University

Craig Howley Ohio University

Steve Klees University of Maryland

Jaekyung Lee SUNY Buffalo
Christopher Lubienski University of Illinois, UrbanaChampaign

Sarah Lubienski University of Illinois, UrbanaChampaign

Samuel R. Lucas University of California, Berkeley

Maria Martinez-Coslo University of Texas, Arlington

William Mathis University of Colorado, Boulder

Tristan McCowan Institute of Education, London

Heinrich Mintrop University of California, Berkeley

Michele S. Moses University of Colorado, Boulder

Julianne Moss University of Melbourne

Sharon Nichols University of Texas, San Antonio

Noga O'Connor University of Iowa

João Paraskveva University of Massachusetts, Dartmouth

Laurence Parker University of Illinois, UrbanaChampaign

Susan L. Robertson Bristol University

John Rogers University of California, Los Angeles

A. G. Rud Purdue University

Felicia C. Sanders The Pennsylvania State University Janelle Scott University of California, Berkeley

Kimberly Scott Arizona State University

Dorothy Shipps Baruch College/CUNY

Maria Teresa Tatto Michigan State University

Larisa Warhol University of Connecticut

Cally Waite Social Science Research Council

John Weathers University of Colorado, Colorado Springs

Kevin Welner University of Colorado, Boulder

Ed Wiley University of Colorado, Boulder

Terrence G. Wiley Arizona State University

John Willinsky Stanford University

Kyo Yamashiro University of California, Los Angeles

* Members of the New Scholars Board 


\section{archivos analíticos de políticas educativas consejo editorial}

Editor: Gustavo E. Fischman (Arizona State University)

Editores. Asociados Alejandro Canales (UNAM) y Jesús Romero Morante (Universidad de Cantabria)

Armando Alcántara Santuario Instituto de Investigaciones sobre la Universidad y la Educación, UNAM México

Claudio Almonacid Universidad Metropolitana de Ciencias de la Educación, Chile

Pilar Arnaiz Sánchez Universidad de Murcia, España

Xavier Besalú Costa Universitat de Girona, España Jose Joaquin Brunner Universidad Diego Portales, Chile

Damián Canales Sánchez Instituto Nacional para la Evaluación de la Educación, México

María Caridad García Universidad Católica del Norte, Chile

Raimundo Cuesta Fernández IES Fray Luis de León, España

Marco Antonio Delgado Fuentes Universidad Iberoamericana, México

Inés Dussel FLACSO, Argentina

Rafael Feito Alonso Universidad Complutense de Madrid, España

Pedro Flores Crespo Universidad Iberoamericana, México

Verónica García Martínez Universidad Juárez Autónoma de Tabasco, México

Francisco F. García Pérez Universidad de Sevilla, España

Edna Luna Serrano Universidad Autónoma de Baja California, México

Alma Maldonado Departamento de Investigaciones Educativas, Centro de Investigación y de Estudios Avanzados, México

Alejandro Márquez Jiménez Instituto de Investigaciones sobre la Universidad y la Educación, UNAM México

José Felipe Martínez Fernández University of California Los Angeles, USA
Fanni Muñoz Pontificia Universidad Católica de Perú

Imanol Ordorika Instituto de Investigaciones Economicas - UNAM, México

Maria Cristina Parra Sandoval Universidad de Zulia, Venezuela

Miguel A. Pereyra Universidad de Granada, España

Monica Pini Universidad Nacional de San Martín, Argentina

Paula Razquin UNESCO, Francia

Ignacio Rivas Flores Universidad de Málaga, España

Daniel Schugurensky Universidad de Toronto-Ontario Institute of Studies in Education, Canadá

Orlando Pulido Chaves Universidad Pedagógica Nacional, Colombia

José Gregorio Rodríguez Universidad Nacional de Colombia

Miriam Rodríguez Vargas Universidad Autónoma de Tamaulipas, México

Mario Rueda Beltrán Instituto de Investigaciones sobre la Universidad y la Educación, UNAM México

José Luis San Fabián Maroto Universidad de Oviedo, España

Yengny Marisol Silva Laya Universidad Iberoamericana, México

Aida Terrón Bañuelos Universidad de Oviedo, España

Jurjo Torres Santomé Universidad de la Coruña, España

Antoni Verger Planells University of Amsterdam, Holanda

Mario Yapu Universidad Para la Investigación Estratégica, Bolivia 


\section{arquivos analíticos de políticas educativas conselho editorial}

Editor: Gustavo E. Fischman (Arizona State University) Editores Associados: Rosa Maria Bueno Fisher e Luis A. Gandin

(Universidade Federal do Rio Grande do Sul)

Dalila Andrade de Oliveira Universidade Federal de Minas Gerais, Brasil

Paulo Carrano Universidade Federal Fluminense, Brasil

Alicia Maria Catalano de Bonamino Pontificia Universidade Católica-Rio, Brasil

Fabiana de Amorim Marcello Universidade Luterana do Brasil, Canoas, Brasil

Alexandre Fernandez Vaz Universidade Federal de Santa Catarina, Brasil

Gaudêncio Frigotto Universidade do Estado do Rio de Janeiro, Brasil

Alfredo M Gomes Universidade Federal de Pernambuco, Brasil

Petronilha Beatriz Gonçalves e Silva Universidade Federal de São Carlos, Brasil

Nadja Herman Pontificia Universidade Católica -Rio Grande do Sul, Brasil

José Machado Pais Instituto de Ciências Sociais da Universidade de Lisboa, Portugal

Wenceslao Machado de Oliveira Jr. Universidade Estadual de Campinas, Brasil
Jefferson Mainardes Universidade Estadual de Ponta Grossa, Brasil

Luciano Mendes de Faria Filho Universidade Federal de Minas Gerais, Brasil

Lia Raquel Moreira Oliveira Universidade do Minho, Portugal

Belmira Oliveira Bueno Universidade de São Paulo, Brasil

António Teodoro Universidade Lusófona, Portugal

Pia L. Wong California State University Sacramento, U.S.A

Sandra Regina Sales Universidade Federal Rural do Rio de Janeiro, Brasil

Elba Siqueira Sá Barreto Fundação Carlos Chagas, Brasil

Manuela Terrasêca Universidade do Porto, Portugal

Robert Verhine Universidade Federal da Bahia, Brasil

Antônio A. S. Zuin Universidade Federal de São Carlos, Brasil 